\title{
Effects of microcystin-LR and cylindrospermopsin on plant-soil systems: A review of their relevance for agricultural plant quality and public health
}

\author{
J. Machado ${ }^{\mathrm{a}}$, A. Campos ${ }^{\mathrm{a}}$, V. Vasconcelos ${ }^{\mathrm{a}, \mathrm{b}}$, M. Freitas ${ }^{\mathrm{a}, \mathrm{c}, *}$ \\ a Interdisciplinary Centre of Marine and Environmental Research (CIIMAR/CIMAR), University of Porto, Rua dos Bragas 289, P 4050-123 Porto, Portugal \\ ${ }^{\mathrm{b}}$ Department of Biology, Faculty of Sciences, University of Porto, Rua do Campo Alegre, P 4069-007 Porto, Portugal \\ ${ }^{\mathrm{c}}$ Polytechnic Institute of Porto, Department of Environmental Health, School of Allied Health Technologies, CISA/Research Center in Environment and \\ Health, Rua de Valente Perfeito, 322, P 440-330 Gaia, Portugal \\ * Corresponding author at: Polytechnic Institute of Porto, Department of Environmental Health, School of Allied Health Technologies, CISA/Research \\ Center in Environment and Health, Rua de Valente Perfeito, 322, P 440-330 Gaia, Portugal. \\ E-mail address: maf@ess.ipp.pt (M. Freitas).
}

\begin{abstract}
A B S T R A C T
Toxic cyanobacterial blooms are recognized as an emerging environmental threat worldwide. Although microcystin-LR is the most frequently documented cyanotoxin, studies on cylindrospermopsin have been increasing due to the invasive nature of cylindrospermopsin-producing cyanobacteria. The number of studies regarding the effects of cyanotoxins on agricultural plants has increased in recent years, and it has been suggested that the presence of microcystin-LR and cylindrospermopsin in irrigation water may cause toxic effects in edible plants. The uptake of these cyanotoxins by agricultural plants has been shown to induce morphological and physiological changes that lead to a potential loss of productivity. There is also evidence that edible terrestrial plants can bioaccumulate cyanotoxins in their tissues in a concentration dependent-manner. Moreover, the number of consecutive cycles of watering and planting in addition to the potential persistence of microcystin-LR and cylindrospermopsin in the environment are likely to result in groundwater contamination. The use of cyanotoxin-contaminated water for agricultural purposes may therefore represent a threat to both food security and food safety. However, the deleterious effects of cyanotoxins on agricultural plants and public health seem to be dependent on the concentrations studied, which in most cases are non-environmentally relevant. Interestingly, at ecologically relevant concentrations, the productivity and nutritional quality of some agricultural plants seem not to be impaired and may even be enhanced. However, studies assessing if the potential tolerance of agricultural plants to these concentrations can result in cyanotoxin and allergen accumulation in the edible tissues are lacking. This review combines the most current information available regarding this topic with a realistic assessment of the impact of cyanobacterial toxins on agricultural plants, groundwater quality and public health.
\end{abstract}

Abbreviations: Adda, 3-amino-9-methoxy-2,6,8-trimethyl-10-phenyldeca-4,6-dienoic acid; APX, ascorbate peroxidase;

CAT, catalase;

CYN, cylindrospermopsin;

Fv/Fm, chlorophyll fluorescence;

GPX, glutathione peroxidase;

GR, glutathione reductase;

GSH, reduced glutathione;

GST, glutathione-S-transferase;

IARC, International Agency for Research on Cancer;

MC(s), Microcystin(s);

MC-LR, Microcystin-LR;

Mdha, N-methyldehydroalanine;

OATP, organic-anion transporting polypeptides;

OECD, Organization for Economic Co-operation and Development;

POD, peroxidase;

$\mathrm{PP}$, protein phosphatases;

PP1, protein phosphatases 1 ;

PP2A, protein phosphatases 2A;

ROS, reactive oxygen species;

SOD, superoxide dismutase;

TDI, tolerable daily intake;

TNFa, tumor necrosis factor $\alpha$;

WHO, World Health Organization

\section{Introduction}

The eutrophication is recognized as an important problem worldwide, being an unequivocal consequence of the intensification of agricultural and industrial activities. In the last decades, its environmental significance has also been enhanced by the global climate change (O'Neil et al., 2012). In eutrophic systems, this process promotes a rapid proliferation of phytoplankton, resulting in the phenomena acknowledged as blooms (Smith et al., 1999; Codd, 2000; Vasconcelos, 2006).

Cyanobacteria, commonly designated as "blue-green algae", are a group of unicellular and multicellular photosynthetic prokaryotes with ubiquitous distribution (Sivonen and Jones, 1999). Currently, there are about 150 cyanobacterial genera identified, which comprise nearly 2000 species (Mur et al., 1999; Hitzfeld et al., 2000). Cyanobacterial blooms can be potentiated by a combination of several environmental factors besides nutrient availability, such as water temperature, light intensity, salinity and water stagnation (Vasconcelos, 2006; Merel 
et al., 2013). These blooms are documented as a threat to human and environmental health because some species produce secondary metabolites (cyanotoxins) with a demonstrated toxic activity to humans and other mammals, birds, fish, crustaceans, mollusks, and zooplankton (Sivonen and Jones, 1999). Due to the production of these metabolites, the Organization for Economic Co-operation and Development (OECD) classified the cyanobacteria as emerging pathogens, even though they do not have the ability to colonize or invade hosts (OECD, 2005). Among the cyanobacterial toxins, microcystins (MCs) are the most widespread group, being microcystin-LR (MC-LR) the main variant in eutrophic freshwaters (WHO, 2011). Nevertheless, concerns are also focused in the increasing occurrence of cylindrospermopsin-producing cyanobacteria, including temperate areas (Kinnear, 2010; Poniedziałek et al., 2012).

Recent studies have suggested that MC-LR and cylindrospermopsin (CYN) cause toxic effects on terrestrial plants (Corbel et al., 2014a). Indeed, the significance of the use of surface water contaminated with cyanotoxins for agricultural purposes is a field of increasing interest. In addition to the potential effects on plant growth and development, this issue may pose concerns for food safety if the possible absorption of toxins by plants can lead to its bioaccumulation in edible tissues. Furthermore, the impact of cyanotoxins on agricultural plants and the ability of cyanotoxins to enter the food chain by this pathway is not fully understood, especially at ecologically relevant concentrations. The concentration of MCs in surface waters used as irrigation source range from 4 to $50 \mu \mathrm{g} / \mathrm{L}$ up to $6500 \mu \mathrm{g} / \mathrm{L}$, however, the higher concentrations would be found in blooms and scums and comprise intracellular and dissolved MCs (Corbel et al., 2014a). Although the studies reporting the concentrations of CYN in the environment are scarce, the concentration of total extracellular CYN in water seem to vary from undetectable values up to $126 \mu \mathrm{g} / \mathrm{L}$ (Corbel et al., 2014a) (see Table 1 of Corbel et al., 2014a). In addition, due to the chemical stability of MC-LR and CYN in irrigation water, these cyanotoxins may leach into the soil, which can compromise groundwater quality and lead to negative public health consequences (Corbel et al., 2014a; Eynard et al., 2000). The aim of this review was to provide the most current information regarding the effects of MC-LR and CYN on plant-soil systems due to the use of contaminated water for irrigation, to better understand the true impact of ecologically relevant concentrations of these cyanotoxins in agricultural plants and the potential implications for groundwater quality and public health.

\subsection{Microcystin-LR}

The most widespread and studied cyanotoxins are the cyclic heptapeptide hepatotoxins, MCs (MW 900-1200) (Dawson, 1998; Sivonen and Jones, 1999). The Microcystis genus is recognized as the most common bloom forming and the main producer of MCs (Sivonen and Jones, 1999). However, other genera such as Anabaena, Oscillatoria, Planktothrix, Nostoc and Anabaenopsis can also produce MCs (Sivonen and Jones, 1999; Hitzfeld et al., 2000; Apeldoorn et al., 2007). The general structure of MCs is: cyclo-(D-alanine- $X$-DMeAsp- $Z$ Adda-D-glutamate-Mdha), in which $X$ and $Z$ are variable L-amino acids, D-MeAsp is D-erythro- $b$-methylaspartic acid, Mdha is N-methyldehydroalanine and Adda is 3-amino-9-methoxy-2,6,8-trimethyl-10-phenyldeca-4,6-dienoic acid (Dawson, 1998). Although more than 100 structural variants have already been reported (Puddick et al., 2014; Qi et al., 2015), MC-LR, mainly produced by Microcystis aeruginosa, is the most studied due to its toxicity and dominance in cyanobacterial blooms (Kuiper-Goodman et al., 1999).

The primary mechanism of toxicity of MC-LR in both animals and higher plants is well recognized and consists in the irreversible inhibition of serine/threonine protein phosphatases 1 and 2A (PP; PP1 and PP2A) by covalent binding (MacKintosh et al., 1990; Dawson, 1998). The induction of oxidative stress by the production of reactive oxygen species (ROS) seems also to be an important biochemical mechanism of MC-LR toxicity in both mammal and plant cells (Pflugmacher, 2004; Pflugmacher et al., 2006, 2007a, b; Pichardo and Pflugmacher, 2011; Zegura et al., 2011; Zhou et al., 2015). Although the target molecules appear to be the same in both animals and higher plants, one relatively unexplored question regarding MCs concerns the mechanism of uptake by plants. In fact, specific transporters of these toxins have not been yet described for vegetable organisms. Nevertheless, several types of membrane transporters with affinity to different peptides and amino acids have been identified (Tegeder and Rentsch, 2010). Since MC-LR is a peptide, it is plausible to put forth the hypothesis that peptide transporters might potentially be involved in the transport of MC-LR in plants. In mammals, once MC-LR has been ingested it concentrates mainly in liver but cannot move across cell membranes easily. It becomes able to enter in hepatocyte cell membranes through active uptake by nonspecific organic-anion transporting polypeptides (OATP) for bile salts (Fischer et al., 2005). Inside the hepatocytes, the inhibition of PP1 and PP2A occurs according to the following two-step mechanism: (1) a non-covalent binding between the ADDA residue of the toxin and the active center of PP1 and PP2A, which seems to be the responsible for the main inhibitory effects of the toxin; (2) a covalent binding between the Mdha residue of the toxin and the cysteine-273 of the catalytic subunit of PP1 or the cysteine-266 of the catalytic subunit of PP2A (Craig et al., 1996; MacKintosh et al., 1990, 1995). Moreover, although the liver is the primary target organ of MC-LR, due to OATP membrane transport system, MC-LR can also affect other organs, such as brain (Kist et al., 2012), heart (Milutinovic et al., 2006), intestine (Zegura et al., 2008), kidney (Qin et al., 2010) and reproductive organs (Wu et al., 2014). MC is able to modulate the expression of oncogenes, proto-oncogenes, cytokines and tumor necrosis factor a (TNFa), affecting cell division, cell survival and apoptosis (IARC, 2010). Epidemiological studies have associated chronic oral exposure to MCLR with the increasing incidence of liver (Yu, 1995; Ueno et al., 1996; Hitzfeld et al., 2000) and colorectal cancer (Zhou et al., 2002). Moreover, the International Agency for Research on Cancer (IARC) classified MC-LR as a possible carcinogenic to humans (IARC, 2010).

\subsection{Cylindrospermopsin}

CYN is a low molecular weight (MW 415) tricyclic alkaloid known for its cytotoxicity in both animal and plant cells. It is considered an emerging threat worldwide due to the progressive distribution of its main producer, Cylindrospermopsis raciborskii (Kinnear, 2010; Poniedzialek et al., 2012). Nevertheless, other cyanobacterial species such as Anabaena bergeii, Aphanizomenon ovalisporum, Raphiodiopsis curvata, Umezakia natans, Aphanizomenon flosaquae, Anabaena lapponica and Lygnbya wollei have been described as CYN producers (Ohtani et al., 1992; Harada et al., 1994; Banker et al., 1997; Li et al., 2001; Schembri et al., 2001; Preussel et al., 2006; Spoof et al., 2006; Seifert et al., 2007). The mechanism of CYN toxicity is still under investigation. So far, it is known that the uptake of this toxin is relatively fast and the complete and irreversible block of protein synthesis occurs after $1 \mathrm{~h}$ of exposure in in vitro assays (Froscio et al., 2003). It is also recognized that the inhibition of protein synthesis occurs at the ribosome during the peptide chain elongation step, with the uracil moiety and the hydroxyl at the $\mathrm{C} 7$ position, being crucial for toxicity (Banker et al., 2001; Froscio et al., 2003). In mammals, CYN can cause liver, kidney, thymus and heart damage and it is considered hepatotoxic, cytotoxic, and neurotoxic; and also a potential carcinogen (Falconer and Humpage, 2006). Additionally, CYN appears to be capable to inhibit glutathione synthesis (Runnegar et al., 1995) and the activation of CYN by cytochrome P450 seems to enhance even more the toxicity (Norris et al., 2002; Humpage et al., 2005). CYN has also two structural variants, 7-epiCYN and deoxy-CYN (Li et al., 2001; Norris et al., 1999) whose origin is still unclear, although it has been hypothesized that they could be 
precursors, variants or degradation products (Banker et al., 2000; Seifert et al., 2007). Nevertheless, both have been proven to be less toxic than CYN (Sukenik et al., 2001).

\section{Effects of MC-LR and CYN in edible plants}

Surface water originating from sources that contain toxic cyanobacteria is often used in agriculture for irrigation. MC-LR can be released from toxic cyanobacterial cells into water during the senescence phase (Apeldoorn et al., 2007) or, in the case of CYN, due to their natural metabolism (Chiswell et al., 1999; Rücker et al., 2007). MCs are very stable and may persist in aquatic systems for weeks after being released from cells (Apeldoorn et al., 2007). Additionally, CYN can persist in water for long periods because it has a very low photodegradation rate under natural conditions (Wörmer et al., 2010).

Because PPs regulate important molecular and cellular processes (Sheen, 1993; Takeda et al., 1994) in vascular plants, the exposure to MC-LR can lead to various perturbations in their physiology and growth (Saqrane et al., 2008). It is well known that the inhibition of PPs in plants affects: (1) tissue development; (2) activation of enzymes involved in $\mathrm{CO}_{2}$ fixation; (3) starch storage; (4) gene expression; (5) regulation of ionic channels; (6) carbon and nitrogen metabolism and (7) the photosynthetic process (Siegl et al., 1990; Sheen, 1993; Smith and Walker, 1996; Luan, 1998; Toroser and Huber, 2000). Furthermore, Garbers et al. (1996) demonstrated that PPs play an important role in auxin transport; therefore, the inhibition of these proteins (PPs) by MC-LR may affect hormone transport, as it was observed in rice (Chen et al., 2013), and disrupt plant growth. MCs can also exert dual effects on plant cells by either stimulating or inhibiting mitosis, depending on the exposure dose (Máthé et al., 2013a).

Studies regarding the effects of CYN on plants are relatively scarce, although it is recognized that this toxin inhibits protein synthesis in eukaryotic cells with similar intensity in both plant and mammalian cell extracts (Terao et al., 1994; Runnegar et al., 2002). The few published studies regarding the effects of CYN on plants indicate: (1) the induction of oxidative stress (Prieto et al., 2011); (2) a reduction in germination rate (Metcalf et al., 2004) and (3) the inhibition of growth (Vasas et al., 2002; Beyer et al., 2009).

In this section, the studies that have reported that MC-LR and CYN produce effects on the physiology and metabolism of agricultural plants will be reviewed and critically discussed in light of potential risks.

\subsection{Effects of $M C-L R$ and $C Y N$ on plant growth and development}

An effect of MCs that has been investigated in several agricultural plants is the inhibition of seed germination (Table 1). This effect attracted the interest of some plant breeding researchers when the results of most studies suggested that the exposure of plants to MC-LRcontaminated water may represent a threat to the quality and productivity of crops, which can then lead to economic losses. In addition, several other studies have demonstrated that MC-LR may have a negative impact on the growth and development of exposed plants (Table 1). Overall, the inhibition effect seems to be dependent on the: (1) plant species; (2) stage of development (seedlings are generally more susceptible than adult plants); (3) time of exposure (prolonged exposures are associated with increased inhibition); (4) range of toxin concentrations applied (positive relation of toxin concentration and inhibition effects); and (5) the nature of the toxin used (e.g., purified toxin or crude extracts). According to some authors, the exposure of plants to MC-LR, either purified or contained in a crude extract, may induce histological, cytological and morphological modifications (McElhiney et al., 2001; Saqrane et al., 2008; Chen et al., 2013; Máthé et al., 2013b), which seem to be related to the negative impacts on the growth and development of the plants.

The effects of CYN on seed germination are still unknown, and to the best of our knowledge, the only study that intended to investigate them demonstrated that these effects are also dependent on the plant species (Table 1). The authors exposed four plant species (Lactuca sativa, Phaseolus vulgaris, Pisum sativum and Solanum lycopersicum) to the same concentration range of CYN $(0.57-57 \mu \mathrm{g} / \mathrm{L})$, but the inhibition of germination occurred only in S. lycopersicum (Silva and Vasconcelos, 2010).

Interestingly, it has been suggested that when a more realistic experimental design is established (i.e., environmentally relevant concentrations, longer exposure period and comparable soil growth conditions), the effects on plant growth are less pronounced. Corbel et al. (2015a) studied the effects of MC-LR in tomatoes following irrigation with water containing 5-100 $\mu \mathrm{g} / \mathrm{L}$ for 90 days and demonstrated that the toxin did not disturb the global growth of the tomatoes. These results are contradictory to those submitted by El Khalloufi et al. (2012), probably because the concentrations used were 20-fold higher. Freitas et al. (2015a) also suggested that lettuce plants are able to cope with low concentrations ( 1 and $10 \mu \mathrm{g} / \mathrm{L}$ ) of MC-LR, CYN and an MC$\mathrm{LR} / \mathrm{CYN}$ mixture by ensuring the maintenance of and even increasing their fresh weight. The growth increase promoted by low concentrations of cyanotoxins can be explained by the hormesis concept, which is characterized by an inverted U-shaped dose response (Bibo et al., 2008).

\subsection{Biochemical effects of $M C-L R$ and $C Y N$ on plants}

The inhibitory effect of MC-LR on photosynthesis has been described in several plant species (Table 2), although the mechanism behind this process remains unknown. A direct effect on the photosynthetic apparatus is hypothesized, which presupposes that the toxin would be assimilated particularly at the root level and then translocated to the leaves by crossing cell barriers. Nevertheless, although this hypothesis cannot be excluded, it is thought that the inhibition occurs through an indirect action of the toxin by the induction of oxidative stress in plants (Peuthert et al., 2007; El Khalloufi et al., 2011). Along with the specific inhibition of PP1 and PP2A (Dawson, 1998), the increase in antioxidant defenses induced by MC-LR suggests that oxidative stress is a major mechanism contributing to the phytotoxicity of this toxin (Pflugmacher et al., 2006, 2007a, b; Pichardo and Pflugmacher, 2011). However, although the inhibition of photosynthetic processes due to increased concentrations of ROS has been documented (Noctor and Foyer, 1998), recently Garda et al. (2016) have shown that under long-term exposure PP inhibition was the primary cause of MC-LR induced mitotic spindle disorders in Vicia faba and not ROS induction. Nevertheless, in a study performed by Gutiérrez-Praena et al. (2014) in which tomato plants were exposed to MC-LR, changes were detected in the function of various proteins related to ATP synthesis, carbon fixation, photosynthesis and carbohydrate metabolism that appear to be linked with the observed decrease in photosynthetic efficiency. A decrease in the expression of some proteins involved in photosynthesis was also observed by Azevedo et al. (2014) in rice plants exposed to $13 \mu \mathrm{g}$ MC-LR/L. In this case, however, the authors did not find significant differences in photosynthetic efficiency. Recently, a study conducted by Corbel et al. (2015a) also demonstrated that, with regard to the photosynthetic process, low concentrations of MC-LR did not alter the concentrations of chlorophyll $a$ and $b$ or the chlorophyll fluorescence (Fv/Fm) of L. esculentum, emphasizing the possibility that environmentally relevant concentrations might not adversely affect exposed plants. We hypothesize that in the exposure of plants to low concentrations of MC-LR, the effects are manifested primarily or solely at the subcellular level, which highlights the importance of choosing suitable biomarkers for this research. It is important to emphasize that we are not assuming that these effects on plants are deleterious; by ensuring plant tolerance, the potential changes may even be beneficial.

As a result of the photosynthetic process, ROS production is a natural phenomenon in plants. However, the excessive formation of 
Table 1

Effects of MC-LR and CYN on seed germination, growth and development of several agricultural plant species.

\begin{tabular}{|c|c|c|c|c|}
\hline Plant species & Endpoint & Effect & $\begin{array}{l}\text { Range of exposure } \\
\text { concentrations }(\mu \mathrm{g} / \mathrm{L})\end{array}$ & Reference \\
\hline \multicolumn{5}{|c|}{ MC - LR } \\
\hline \multirow[t]{2}{*}{ Brassica napus } & Germination Rate & $\downarrow$ & $600-3000 b$ & Chen et al., 2004 \\
\hline & Height of seedlings & $\downarrow$ & $120-3000 \mathrm{~b}$ & \\
\hline Brassica rapa & Shoot length & $\downarrow$ & $400-6400 b$ & Chen et al., 2012b \\
\hline \multirow[t]{4}{*}{ Lactuca sativa } & Root growth & $\downarrow$ & $5.9-56.4 \mathrm{~b}$ & Pereira et al., 2009 \\
\hline & Root fresh weight & $\uparrow$ & $1-100 \mathrm{~b}$ & Freitas et al., 2015a \\
\hline & Fresh weight of leaves & $\uparrow$ & $1-50 \mathrm{a}$ & \\
\hline & & $\downarrow$ & $100 \mathrm{a}$ & \\
\hline \multirow[t]{6}{*}{ Lens esculenta } & Germination Rate & $\downarrow$ & $8700-11,600 b$ & Saqrane et al., 2008 \\
\hline & $\begin{array}{c}\text { Epicotyl length; primary root length; lateral root } \\
\text { number }\end{array}$ & $\downarrow$ & $11,600 \mathrm{~b}$ & \\
\hline & Height (30th day) & $\downarrow$ & $1050-42,000 \mathrm{~b}$ & \\
\hline & Leaf number; (30th day) & $\downarrow$ & $4200 \mathrm{~b}$ & \\
\hline & Fresh weight & $\downarrow$ & $500-4200 \mathrm{~b}$ & \\
\hline & Dry weight & $\downarrow$ & $1050-4200 b$ & \\
\hline \multirow[t]{2}{*}{ Lepidium sativum } & Fresh weight; (6th day) & $\downarrow$ & $10 \mathrm{a}$ and $\mathrm{b}$ & Gehringer et al., 2003 \\
\hline & Root and leaf length & $\downarrow$ & $1 \mathrm{a}$ and $\mathrm{b}$ & \\
\hline \multirow[t]{2}{*}{ Lycopersicon esculentum } & Germination Rate & $\downarrow$ & $16,680-22,240 b$ & El Khalloufi et al., 2012 \\
\hline & Fresh biomass, stem length & $\downarrow$ & $2220-22,240 \mathrm{~b}$ & \\
\hline Malus pumila & Growth & $\downarrow$ & $300-3000 b$ & Chen et al., 2010 \\
\hline \multirow[t]{6}{*}{ Medicago sativa } & Germination Rate & $\downarrow$ & $5 \mathrm{a}$ and $\mathrm{b}$ & Pflugmacher et al., 2006 \\
\hline & Primary root length & $\downarrow$ & & \\
\hline & Germination Rate & $\downarrow$ & $2220-22,240 \mathrm{~b}$ & El Khalloufi et al., 2011 \\
\hline & $\begin{array}{l}\text { Plants length; nodules number; biomass (30th } \\
\text { day) }\end{array}$ & $\downarrow$ & $2222-22,240 \mathrm{~b}$ & \\
\hline & Root length & $\downarrow$ & $11,120-22,240 \mathrm{~b}$ & \\
\hline & Dry weight & $\downarrow$ & $10-20 \mathrm{~b}$ & El Khalloufi et al., 2013 \\
\hline \multirow[t]{5}{*}{ Oryza sativa } & Fresh weigh and length of roots & $\downarrow$ & $120-3000 \mathrm{~b}$ & Chen et al., 2004 \\
\hline & Dry weight of roots & $\downarrow$ & $24-600 b$ & \\
\hline & Height of seedlings & $\downarrow$ & $600-3000 b$ & \\
\hline & $\begin{array}{c}\text { Fresh weight of root; length and number of crown } \\
\text { root }\end{array}$ & $\downarrow$ & $2000-4000 b$ & Chen et al., 2013 \\
\hline & Number of lateral root on seminal root & $\downarrow$ & $1000-4000 b$ & \\
\hline \multirow[t]{5}{*}{ Pisum sativum } & Germination Rate & $\downarrow$ & $1600-11,600 \mathrm{~b}$ & Saqrane et al., 2008 \\
\hline & $\begin{array}{c}\text { Epicotyl length; primary root length; lateral root } \\
\text { number }\end{array}$ & $\downarrow$ & $1600 \mathrm{~b}$ & \\
\hline & Height (30th day) & $\downarrow$ & $500-4200 b$ & Saqrane et al., 2009 \\
\hline & Leaf number (30th day) & $\downarrow$ & $1050-4200 \mathrm{~b}$ & \\
\hline & Fresh and dry weight & $\downarrow$ & $500-4200 \mathrm{~b}$ & \\
\hline \multirow[t]{5}{*}{ Sinapis alba } & Growth & $\downarrow$ & $2000 \mathrm{a}$ & $\begin{array}{l}\text { Kurki-Helasmo and } \\
\text { Meriluoto, } 1998\end{array}$ \\
\hline & $\begin{array}{l}\text { Fresh mass, length (total, hypocotyl, cotyledon, } \\
\text { root), primary root growth, lateral root number }\end{array}$ & $\downarrow$ & $3500-30,000 \mathrm{~b}$ & M-Hamvas et al., 2003 \\
\hline & Growth & $\downarrow$ & $500-5000 \mathrm{~b}$ & McElhiney et al., 2001 \\
\hline & Growth & $\downarrow$ & $7800 \mathrm{~b}$ & Vasas et al., 2002 \\
\hline & & & $18,200 \mathrm{a}$ & \\
\hline \multirow[t]{2}{*}{ Solanum tuberosum } & Fresh weight; shoot length & $\downarrow$ & $500-5000 \mathrm{~b}$ & McElhiney et al., 2001 \\
\hline & Number of roots & $\downarrow$ & $10-500 \mathrm{~b}$ & \\
\hline $\begin{array}{l}\text { Spinacia oleracea (var. Balta. Saran, } \\
\text { Gamma, Merlin) }\end{array}$ & Growth & $\downarrow$ & $0.5 \mathrm{~b}$ & Pflugmacher et al., 2007a \\
\hline $\begin{array}{l}\text { Spinacia oleracea (var. Parys, } \\
\text { Matador) }\end{array}$ & Number of leaves; leaf size & $\downarrow$ & & \\
\hline \multirow{2}{*}{ Triticum aestivum } & Germination Rate & $\downarrow$ & $0.5 \mathrm{a}$ and $\mathrm{b}$ & Pflugmacher et al., 2007b \\
\hline & Shoot and root length & $\downarrow$ & & \\
\hline \multirow[t]{4}{*}{ Triticum durum } & Germination Rate & $\downarrow$ & $2900-11,600 \mathrm{~b}$ & Saqrane et al., 2008 \\
\hline & $\begin{array}{c}\text { Epicotyl length; primary root length; lateral root } \\
\text { number }\end{array}$ & $\downarrow$ & $1600 \mathrm{~b}$ & \\
\hline & Height (30th day), fresh and dry weight & $\downarrow$ & $500-4200 \mathrm{~b}$ & Saqrane et al., 2009 \\
\hline & Leaf number (30th day) & $\downarrow$ & $4200 \mathrm{~b}$ & \\
\hline \multirow[t]{2}{*}{ Vicia faba } & Germination Rate & $\downarrow$ & $50-100 \mathrm{~b}$ & Lahrouni et al., 2012 \\
\hline & $\begin{array}{l}\text { Shoot dry weight, root length, root and nodule dry } \\
\text { weight, total number of nodules }\end{array}$ & $\downarrow$ & & \\
\hline \multirow[t]{6}{*}{ Zea mays } & Germination Rate & $\downarrow$ & $5 \mathrm{a}$ and $\mathrm{b}$ & Pflugmacher, 2007 \\
\hline & Shoot and root length & $\downarrow$ & & \\
\hline & Germination Rate & $\downarrow$ & $2900-11,600 \mathrm{~b}$ & Saqrane et al., 2008 \\
\hline & $\begin{array}{c}\text { Epicotyl length; primary root length; lateral root } \\
\text { number }\end{array}$ & $\downarrow$ & $11,600 \mathrm{~b}$ & \\
\hline & Height (30th day); fresh weight & $\downarrow$ & $500-4200 \mathrm{~b}$ & Saqrane et al., 2009 \\
\hline & Leaf number (30th day) & $\downarrow$ & $1050-4200$ & (continued on next \\
\hline
\end{tabular}


Table 1 (continued)

\begin{tabular}{|c|c|c|c|c|}
\hline Plant species & Endpoint & Effect & $\begin{array}{c}\text { Range of exposure } \\
\text { concentrations }(\mu \mathrm{g} / \mathrm{L})\end{array}$ & Reference \\
\hline \multicolumn{5}{|c|}{ CYN } \\
\hline \multirow[t]{5}{*}{ Lactuca sativa } & Root length & $\uparrow$ & $0.57-5.7 b$ & Silva and Vasconcelos, 2010 \\
\hline & & $\downarrow$ & $57 \mathrm{~b}$ & \\
\hline & Stem length & $\uparrow$ & $0.57-57 b$ & \\
\hline & Fresh weigh of roots & $\uparrow$ & $1-100 \mathrm{a}$ & Freitas et al., 2015a \\
\hline & Fresh weigh of leaves & $\downarrow$ & $100 \mathrm{a}$ & \\
\hline Nicotiana tabacum & Germination Rate & $\downarrow$ & $5000-10,000,000 \mathrm{a}$ & Metcalf et al., 2004 \\
\hline Phaseolus vulgaris & Root length & $\uparrow$ & $0.57-57 b$ & Silva and Vasconcelos, 2010 \\
\hline \multirow[t]{2}{*}{ Pisum sativum } & Root length & $\downarrow$ & $0.57-57 b$ & Silva and Vasconcelos, 2010 \\
\hline & Stem length & $\uparrow$ & & \\
\hline Oryza sativa & Root fresh weight & $\uparrow$ & $2.5 \mathrm{~b}$ & Prieto et al., 2011 \\
\hline \multirow[t]{2}{*}{ Sinapis alba } & Lateral root emergence & $\uparrow$ & 10 & Máthé et al., 2013b \\
\hline & & $\downarrow$ & $5000-20,000 \mathrm{a}$ & \\
\hline \multirow[t]{3}{*}{ Lycopersicon esculentum } & Germination rate & $\downarrow$ & $0.57-57 \mathrm{~b}$ & Silva and Vasconcelos, 2010 \\
\hline & Root length & $\downarrow$ & & \\
\hline & Stem length & $\downarrow$ & & \\
\hline \multirow[t]{4}{*}{ Vicia faba } & Epicotyl and main root elongation & $\uparrow$ & $100 \mathrm{a}$ & Garda et al., 2015 \\
\hline & & $\downarrow$ & $5000-20,000 a$ & \\
\hline & Number of lateral root & $\uparrow$ & 2500 a & \\
\hline & & $\downarrow$ & $10,000-20,000 a$ & \\
\hline
\end{tabular}

$\uparrow$ Increased in comparison to control group; $\downarrow$ Decreased in comparison to control group; a, pure toxin; b, crude extract.

these molecules is often triggered by external factors, such as various xenobiotics and their biotransformation, which may lead to damage of the DNA, proteins, carbohydrates and lipids. Plants have a welldeveloped antioxidant defense system that works to relieve the negative effects caused by ROS. It consists of a network of enzymes, such as superoxide dismutase (SOD), catalase (CAT), peroxidase (POD), glutathione peroxidase (GPX), ascorbate peroxidase (APX), glutathione-Stransferase (GST), glutathione reductase (GR) and also a non-enzymatic complex comprised of reduced glutathione (GSH) and vitamins (e.g., ascorbic acid as well as phenolic, tocopherol and carotenoid compounds) (Cadenas, 1995; Apel and Hirt, 2004). The evaluations of changes in the enzymatic and non-enzymatic components of plants have also demonstrated the promotion of oxidative stress by MC-LR (Table 2). For instance, Peuthert et al. (2007) detected cellular damage (lipid peroxidation) in both the roots and shoots of several agricultural plants (Pisum sativum, Cicer arietinum, Vigna radiata, Phaseolus vulgaris, Glycine max, Medicago sativa, Lens culinaris, Triticum aestivum and Zea mays) that were exposed to MC-LR, either purified or in crude extract. These observations highlighted the impact of cyanotoxins on the nutritional value of plants because the content of antioxidants can be changed as a physiological response mechanism. Furthermore, some studies have demonstrated that MC-LR can be responsible for changes in the mineral content of plants; however, the existing information on this topic is still scarce. In general, the macro mineral content of the roots is increased after exposing the plants to MC-LR (Saqrane et al., 2009; El Khalloufi et al., 2012; Lahrouni et al., 2013) in a concentration-dependent manner (Saqrane et al., 2009; El Khalloufi et al., 2012). Lahrouni et al. (2013) suggest that these changes may be derived from a disruption of the membrane permeability caused by MC-LR. However, it is important to note that almost all of the studies that have been performed used crude extract containing MC-LR (Saqrane et al., 2009; El Khalloufi et al., 2012; Lahrouni et al., 2013) instead of pure toxin, which can be relevant from an ecological point of view. Nevertheless, doubt remains regarding whether the effect is the outcome of the negative impact of the toxin in plants or a consequence of the increase in minerals provided by the extract because it is known that these extracts are rich in minerals (Rajeshwari and Rajashekhar, 2011). The exposure of Lactuca sativa (Freitas et al., 2015a) and Vicia faba (Lahrouni et al., 2013) to purified MC-LR and MC-LR contained in crude extract, respectively, generally produced a decrease in the mineral content of the leaves. These contradictory results may be associated with differences in the concentrations of the exposures, which were much lower in the latter experiments. After being assimilated by the roots, minerals are translocated to various parts of the plant where they are used in numerous biological functions (Taiz and Zeiger, 2002), such as ensuring the growth and development of the plant (Grusak, 2001). The oxidative stress and cellular damage potentiated in the roots by MC-LR may considerably affect the translocation of nutrients and water to the aerial tissues of the plants, and may therefore explain the decrease in mineral content and even the impairment in the growth and development of leaves (Tables 1, 2).

As for the effects on plant growth, the induction of biochemical effects due to CYN exposure is poorly documented. This cyanotoxin seems to generate stress/defense responses such as the lignification of cell walls and the formation of a callus-like tissue in in vitro cultures, and this may play a role in the inhibition of toxin uptake (Beyer et al., 2009; Máthé et al., 2013a). Moreover, a study conducted by Prieto et al. (2011) demonstrated that CYN is able to induce oxidative stress after $48 \mathrm{~h}$ of exposure to $2.5 \mu \mathrm{g}$ CYN/L. This concentration of CYN appears to be sufficient to cause an increase in GST and GPx activities in the roots, contrary to what occurred in the leaves, where a non-significant effect was observed. A study developed by Freitas et al. (2015a) also showed an increase in the GST activity in the roots of lettuce plants exposed to CYN, which seemed to be time- and concentrationdependent. However, the GPx activity was significantly decreased in both the roots and the leaves of lettuce plants exposed to $100 \mu \mathrm{g} \mathrm{CYN} / \mathrm{L}$ for 5 days.

Although Freitas et al. (2015b) reported a significantly increased abundance of proteins involved in photosynthesis in lettuce plants exposed to CYN, the effects of CYN in this process have not yet been investigated; the effects on the mineral content, however, have already been reported. Freitas et al. (2015a) found that the exposure of lettuce to purified CYN, in contrast to MC-LR, produced an enhancement in leaf micro ( $\mathrm{Fe}, \mathrm{Mn}, \mathrm{Cu}, \mathrm{Zn}, \mathrm{Mo}$ ) and macro ( $\mathrm{Ca}, \mathrm{Mg}, \mathrm{P}, \mathrm{K}, \mathrm{Na}$ ) mineral content. Because crop plants generally only need small amounts of micronutrients, the excessive increase in concentrations of these elements in the leaves of the lettuce plants exposed to CYN could provoke impairment in their metabolism and physiology. 
Table 2

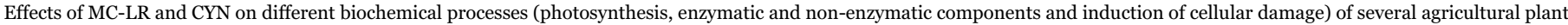
species.

\begin{tabular}{|c|c|c|c|c|}
\hline Plant species & Endpoint & Effect & $\begin{array}{l}\text { Range of exposure concentrations } \\
(\mu \mathrm{g} / \mathrm{L})\end{array}$ & Reference \\
\hline \multicolumn{5}{|c|}{ MC - LR } \\
\hline \multirow[t]{2}{*}{ Brassica napus } & SOD & $\downarrow$ & $24-3000 \mathrm{~b}$ & Chen et al., 2004 \\
\hline & POD & $\uparrow$ & $120-3000 \mathrm{~b}$ & \\
\hline Brassica rapa & $\mathrm{Cu} / \mathrm{Zn}-\mathrm{SOD} ; \mathrm{APX}$ and CAT & $\uparrow$ & $4230 \mathrm{~b}$ & Chen et al., 2012b \\
\hline \multirow[t]{10}{*}{ Lactuca sativa } & Shoot Mineral Content (Ca, Mg, K, P, Mn, Fe, Zn, Cu, Mo) & $\downarrow$ & $10-100 \mathrm{a}$ & Freitas et al., 2015a \\
\hline & GST (Roots) & $\uparrow$ & & \\
\hline & GPx (Roots) & $\downarrow$ & $100 \mathrm{a}$ & \\
\hline & Net photosynthetic rate & $\uparrow$ & $0.65-2.5 b$ & Bittencourt-Oliveira et al., \\
\hline & Transpiration & $\uparrow$ & & 2016 \\
\hline & Intercellular $\mathrm{CO}_{2}$ concentration & $\uparrow$ & & \\
\hline & Stomatal conductance & $\uparrow$ & & \\
\hline & GST & $\downarrow$ & $0.65-13 b$ & \\
\hline & SOD & $\uparrow$ & $2.5-13 b$ & \\
\hline & CAT & $\uparrow$ & $13 \mathrm{~b}$ & \\
\hline \multirow{2}{*}{ Lens esculenta } & Total chlorophyll content $(\mathrm{a}+\mathrm{b})$ & $\downarrow$ & $2100-4200 \mathrm{~b}$ & Saqrane et al., 2009 \\
\hline & Root Mineral Content (Na; N, K, P and Ca) & $\uparrow$ & $500-4200 \mathrm{~b}$ & \\
\hline \multirow[t]{4}{*}{ Lepidium sativum } & GST; GPx & $\uparrow$ & $1-10 \mathrm{a}$ and $\mathrm{b}$ & Gehringer et al., 2003 \\
\hline & Lipid peroxidation & $\uparrow$ & $0.5 \mathrm{a}$ and $\mathrm{b}$ & Stüven and Pflugmacher, \\
\hline & $\alpha$ - and $\beta$-tocopherol, GST; GPx; GR & $\uparrow$ & & 2007 \\
\hline & $\Upsilon$ - and $\delta$-tocopherol & $\downarrow$ & & \\
\hline Lycopersicon esculentum/ & Fv/Fm fluorescence & $\downarrow$ & $2220-22,240 \mathrm{~b}$ & El Khalloufi et al., 2012 \\
\hline \multirow[t]{4}{*}{ Solanum tuberosum } & POD, Phenols content, Protein Content & $\uparrow$ & & \\
\hline & Root Mineral Content (Na; K and Ca) & $\uparrow$ & & \\
\hline & Fv/Fm fluorescence & $\downarrow$ & $100 \mathrm{~b}$ & $\begin{array}{l}\text { Gutiérrez-Praena et al., } \\
\qquad 2014\end{array}$ \\
\hline & Total chlorophyll content $(a+b)$ & $\downarrow$ & $50-5000$ a & McElhiney, et al., 2001 \\
\hline Malus pumila & POD, SOD & $\uparrow$ & $300-3000 \mathrm{~b}$ & Chen et al., 2010 \\
\hline \multirow[t]{7}{*}{ Medicago sativa } & $\begin{array}{l}\text { SOD, CAT, POD, GST, GR, Lipid peroxidation, Protein } \\
\text { content }\end{array}$ & $\uparrow$ & $5 \mathrm{a}$ and $\mathrm{b}$ & Pflugmacher et al., 2006 \\
\hline & Fv/Fm fluorescence & $\downarrow$ & $11,120-22,240 \mathrm{~b}$ & El Khalloufi et al., 2011 \\
\hline & POD, Phenols content & $\uparrow$ & & \\
\hline & Protein Content & $\uparrow$ & $2220-22,240 \mathrm{~b}$ & \\
\hline & $\alpha$ - and $\beta$-tocopherol & $\uparrow$ & $0.5-5 \mathrm{a}$ and $\mathrm{b}$ & $\begin{array}{c}\text { Peuthert and } \\
\text { Pflugmacher, } 2010\end{array}$ \\
\hline & Total chlorophyll content $(a+b)$ & $\downarrow$ & $5-20 \mathrm{~b}$ & El Khalloufi et al., 2013 \\
\hline & POD, CAT, PPO & $\uparrow$ & $10-20 \mathrm{~b}$ & \\
\hline \multirow[t]{2}{*}{ Oryza sativa } & Phenols content & $\uparrow$ & $24-120 \mathrm{~b}$ & Chen et al., 2004 \\
\hline & GST & $\uparrow$ & $50 \mathrm{~b}$ & Prieto et al., 2011 \\
\hline \multirow[t]{2}{*}{ Pisum sativum } & Fv/Fm fluorescence & $\uparrow$ & $500-4200 \mathrm{~b}$ & Saqrane et al., 2009 \\
\hline & Root Mineral Content (Na; N, K, P and Ca) & $\uparrow$ & $500-4200 \mathrm{~b}$ & \\
\hline \multirow[t]{2}{*}{ Sinapis alba } & Anthocyanin content & $\downarrow$ & $3500-30,000 \mathrm{~b}$ & M-Hamvas et al., 2003 \\
\hline & PP1 and 2A activity & $\downarrow$ & $10-10,000 \mathrm{a}$ & Máthé et al., 2013b \\
\hline Solanum tuberosum & Total chlorophyll content $(a+b)$ & $\downarrow$ & $50-5000$ a & McElhiney, et al., 2001 \\
\hline \multirow{2}{*}{ Spinacea oleracea } & Photosynthetic oxygen production & $\downarrow$ & $0.5 \mathrm{~b}$ & Pflugmacher et al., 2007a \\
\hline & $\begin{array}{l}\text { CAT; SOD; POD; GST (microsomal and cytosolic); GR, } \\
\text { Ascorbate; dehydroascorbate; } \alpha-\text { and }-\Upsilon \text {-tocopherol }\end{array}$ & $\uparrow$ & & \\
\hline \multirow[t]{2}{*}{ Triticum aestivum } & $\begin{array}{l}\text { Total chlorophyll content }(a+b) \text {; photosynthetic oxygen } \\
\text { production }\end{array}$ & $\downarrow$ & $0.5 \mathrm{a}$ and $\mathrm{b}$ & Pflugmacher et al., 2007b \\
\hline & GST; GPx; GR & $\uparrow$ & & \\
\hline \multirow{2}{*}{ Triticum durum } & Fv/Fm fluorescence & $\downarrow$ & $500-4200 \mathrm{~b}$ & Saqrane et al., 2009 \\
\hline & Root Mineral Content (Na; N, K, P and Ca) & $\uparrow$ & & \\
\hline \multirow[t]{8}{*}{ Vicia faba } & Total chlorophyll content $(a+b)$ & $\downarrow$ & $100 \mathrm{~b}$ & Lahrouni et al., 2013 \\
\hline & Fv/Fm fluorescence & $\downarrow$ & $50-100 \mathrm{~b}$ & \\
\hline & POD; CAT, PAL; PPO; phenolic compounds & $\uparrow$ & & \\
\hline & Shoot Mineral Content (Ca, N and K) & $\downarrow$ & & \\
\hline & Shoot Mineral Content $(\mathrm{Na})$ & $\uparrow$ & & \\
\hline & Root Mineral Content (N and $\mathrm{P}$ ) & $\downarrow$ & & \\
\hline & Root Mineral Content (Na) & $\uparrow$ & & \\
\hline & & $\downarrow$ & $1000-20,000 \mathrm{a}$ & Garda et al., 2016 \\
\hline Zea mays & POD & $\uparrow$ & $5 \mathrm{a}$ and $\mathrm{b}$ & Pflugmacher, 2007 \\
\hline & Total chlorophyll content $(a+b)$ & $\downarrow$ & $4200 \mathrm{~b}$ & Saqrane et al., 2009 \\
\hline & Fv/Fm fluorescence & $\downarrow$ & $500-4200 \mathrm{~b}$ & \\
\hline & Root Mineral Content (Na; N, K, P and Ca) & $\uparrow$ & & \\
\hline & CYN & & & \\
\hline Lactuca sativa & $\begin{array}{l}\text { Shoot Mineral Content - (Na, P, Mn, Fe, } \\
\text { Zn, } \mathrm{Cu}, \mathrm{Mo})\end{array}$ & $\uparrow$ & $1-100 \mathrm{a}$ & Freitas et al., 2015a \\
\hline & GST (Roots) & $\uparrow$ & & \\
\hline Nicotiana tabacum & Protein synthesis & $\downarrow$ & $138,000 \mathrm{a}$ & Metcalf et al., 2004 \\
\hline Oryza sativa & GST and GPx (Roots) & $\uparrow$ & $2.5 \mathrm{~b}$ & Prieto et al., 2011 \\
\hline Sinapis alba & de novo protein synthesis in roots & $\downarrow^{*}$ & 18,000 a & Garda et al., 2015 \\
\hline & PP1 and 2A activity & $\downarrow$ & $10-10,000 \mathrm{a}$ & Máthé et al., 2013b \\
\hline
\end{tabular}

$\uparrow$ Increased in comparison to control group; $\downarrow$ Decreased in comparison to control group; $\downarrow$ * Delayed in comparison to control group; a, pure toxin; b, crude extract. 
Table 3

Accumulation of MC-LR in several edible plant species and the daily consumption calculated based on the concentration reported in plant tissues.

\begin{tabular}{|c|c|c|c|c|c|c|}
\hline Plant species & $\begin{array}{l}\text { Concentration of } \\
\text { exposure }(\mu \mathrm{g} / \mathrm{L})\end{array}$ & $\begin{array}{l}\text { Exposure time } \\
\text { (days) }\end{array}$ & Analyzed organ & $\begin{array}{l}\text { Concentration reported in } \\
\text { plant tissues (ng/g F.W) }\end{array}$ & $\begin{array}{l}\text { Daily consumption } \\
(\mu \mathrm{g} / \mathrm{kg} \mathrm{BW})^{\mathrm{a}}\end{array}$ & Reference \\
\hline \multirow{4}{*}{ Brassica napus } & 24 & \multirow[t]{4}{*}{10} & \multirow{4}{*}{$\begin{array}{l}\text { Extract of plant } \\
\text { (excluding roots) }\end{array}$} & 2.61 & 0.01 & \multirow[t]{4}{*}{ Chen et al., 2004} \\
\hline & 120 & & & 8.32 & 0.02 & \\
\hline & 600 & & & 123.57 & 0.31 & \\
\hline & 3000 & & & 651 & 1.63 & \\
\hline Cicer arietinum & 5 & 1 & Shoots & $\approx 10$ & $\approx 0.03$ & $\begin{array}{l}\text { Peuthert et al., } \\
2007\end{array}$ \\
\hline Glycine $\max$ & 5 & 1 & Shoots & $\approx 17$ & $\approx 0.04$ & $\begin{array}{l}\text { Peuthert et al., } \\
2007\end{array}$ \\
\hline \multirow[t]{3}{*}{ Lactuca sativa } & 2 & \multirow[t]{3}{*}{15} & \multirow[t]{3}{*}{ Leaf } & $\approx 33$ & \multirow[t]{3}{*}{$0.02-\mathbf{0 . 0 9}^{\mathrm{b}}$} & Bittencourt- \\
\hline & 5 & & & $\approx 103$ & & Oliveira et al., 2016 \\
\hline & 10 & & & $\approx 143$ & & \\
\hline \multirow[t]{6}{*}{ Lactuca sativa } & \multirow[t]{3}{*}{5} & 1 & \multirow[t]{6}{*}{ Leaf } & $\approx 1.30^{\mathrm{c}}$ & $0.02^{\mathrm{b}}$ & \multirow{6}{*}{$\begin{array}{l}\text { Cordeiro-Araújo } \\
\text { et al., } 2016\end{array}$} \\
\hline & & 4 & & $\approx 1.59^{c}$ & $0.03^{\mathrm{b}}$ & \\
\hline & & 7 & & $\approx 2.05^{\mathrm{c}}$ & $0.03^{\mathrm{b}}$ & \\
\hline & \multirow[t]{3}{*}{10} & 1 & & $\approx 2.94^{\mathrm{c}}$ & $0.05^{\mathrm{b}}$ & \\
\hline & & 4 & & $\approx 3.83^{\mathrm{c}}$ & $0.06^{b}$ & \\
\hline & & 7 & & $\approx 4.04^{\mathrm{c}}$ & $\mathbf{0 . 0 7} 7^{\mathrm{b}}$ & \\
\hline Lens culinarian & 5 & 1 & Shoots & $\approx 20$ & $\approx 0.05$ & $\begin{array}{l}\text { Peuthert et al., } \\
2007\end{array}$ \\
\hline \multirow{10}{*}{$\begin{array}{l}\text { Lycopersicon } \\
\text { esculentum }\end{array}$} & \multirow{2}{*}{100} & \multirow{2}{*}{7} & Green Fruits & $\approx 5$ & $\approx 0.01$ & \multirow{2}{*}{$\begin{array}{l}\text { Gutiérrez-Praena } \\
\text { et al., } 2014\end{array}$} \\
\hline & & & Mature Fruits & $\approx 10$ & $\approx 0.03$ & \\
\hline & \multirow[t]{2}{*}{5} & \multirow[t]{8}{*}{90} & Leaves & n.d & - & \multirow[t]{8}{*}{ Corbel et al., 2016} \\
\hline & & & Roots & $\approx 4.5$ & $\approx 0.01$ & \\
\hline & \multirow[t]{2}{*}{20} & & Leaves & $\approx 0.29$ & $\approx 0.00$ & \\
\hline & & & Roots & $\approx 4.8$ & $\approx 0.01$ & \\
\hline & \multirow[t]{2}{*}{50} & & Leaves & $\approx 0.33$ & $\approx 0.00$ & \\
\hline & & & Roots & $\approx 5.7$ & $\approx 0.01$ & \\
\hline & \multirow[t]{2}{*}{100} & & Leaves & $\approx 0.55$ & $\approx 0.00$ & \\
\hline & & & Roots & $\approx 8.1$ & $\approx 0.02$ & \\
\hline \multirow[t]{3}{*}{ Malus pumila } & 30 & \multirow[t]{3}{*}{14} & \multirow[t]{3}{*}{ Shoots } & 14.76 & 0.04 & Chen et al., 2010 \\
\hline & 300 & & & 43.94 & 0.11 & \\
\hline & 3000 & & & 510.23 & 1.28 & \\
\hline Medicago sativa & 5 & 1 & Shoots & $\approx 27$ & $\approx 0.07$ & $\begin{array}{l}\text { Peuthert et al., } \\
2007\end{array}$ \\
\hline Oryza sativa & 120 & 10 & Extract of plant & 2.94 & 0.01 & Chen et al., 2004 \\
\hline & 600 & & (excluding roots) & 5.12 & 0.01 & \\
\hline & 3000 & & & 5.40 & 0.01 & \\
\hline Pisum sativum & 5 & 1 & Shoots & $\approx 18$ & $\approx 0.05$ & $\begin{array}{l}\text { Peuthert et al., } \\
2007\end{array}$ \\
\hline Phaseolus vulgaris & 5 & 1 & Shoots & $\approx 38$ & $\approx 0.10$ & $\begin{array}{l}\text { Peuthert et al., } \\
2007\end{array}$ \\
\hline $\begin{array}{l}\text { Vigna radiata } \\
\text { green }\end{array}$ & 5 & 1 & Shoots & $\approx 18$ & $\approx 0.05$ & $\begin{array}{l}\text { Peuthert et al., } \\
2007\end{array}$ \\
\hline Vigna radiata red & 5 & 1 & Shoots & $\approx 4$ & $\approx 0.01$ & $\begin{array}{l}\text { Peuthert et al., } \\
2007\end{array}$ \\
\hline Triticum aestivum & 5 & 1 & Shoots & $\approx 28$ & $\approx \mathbf{0 . 0 7}$ & $\begin{array}{l}\text { Peuthert et al., } \\
2007\end{array}$ \\
\hline Zea mays & 5 & 1 & Shoots & $\approx 40$ & $\approx 0.10$ & $\begin{array}{l}\text { Peuthert et al., } \\
2007\end{array}$ \\
\hline
\end{tabular}

Daily consumption values highlighted in bold indicate TDI values higher than those recommended by WHO. n.d., non-detectable.

${ }^{a}$ The daily consumption of MC was calculated assuming that a person of $60 \mathrm{~kg}$ consumes $150 \mathrm{~g}$ of the vegetable species per day.

b The daily consumption of MC was calculated by the authors assuming that a person of $60 \mathrm{~kg}$ consumes $40 \mathrm{~g}$ of lettuce leaves per day.

${ }^{\mathrm{c}}$ Value expressed in $\mu \mathrm{g}$ per $40 \mathrm{~g}$ of lettuce leaves.

\section{Accumulation of MC-LR and CYN in edible tissues of plants}

The ability of MC-LR and CYN to accumulate in the tissues of several agricultural plants has been described previously, and it was recently reviewed by Corbel et al. (2014a). Nonetheless, the mechanism of MC-LR and CYN uptake by plants is relatively unexplored. The accumulation of MC-LR in plants appears to occur in a time- and concentration-dependent manner (for relatively short periods of exposure, $\leq 15$ days), and a higher uptake in the roots has frequently been observed (Table 3). Indeed, it has been suggested by several authors that, in general, the toxin is absorbed via the root system, and it is then translocated to the shoots (Peuthert et al., 2007; Crush et al., 2008; Saqrane et al., 2009). As above mentioned, specific transporters of MCLR have not yet been described, although several types of plant membrane transporters with affinities for different peptides and amino acids have been identified (Tegeder and Rentsch, 2010). Because MCLR is a peptide, the hypothesis that peptide transporters might potentially be involved in toxin uptake by plants is plausible. In addition, a study developed by Romero-Oliva et al. (2014) suggests that MC-LR translocation goes further into fruits and even into new plants via their seeds as they observed in Capsicum annum. Gutiérrez-Praena et al. (2014) have already described the accumulation of MC-LR in L. esculentum fruits (tomato). However, recently, Corbel et al. (2016) have shown that for the same range of exposure concentrations $(100 \mu \mathrm{g}$ eq. MC-LR/L) the accumulation of MC-LR in the $S$. lycopersicum cv. MicroTom, cultivated in a soil-plant system, occurred only in leaves and roots but not in tomato fruits. These contradictory results may be explained by the duration of exposure experiment, which was of 2 weeks in the study of Gutiérrez-Praena 
et al. (2014) and 90 days in the study of Corbel et al. (2016). Indeed, Gutiérrez-Praena et al. (2014) have detected MC-LR in tomato fruits only in the first week of the exposure experiment, since in the second week the MC-LR concentration in fruits decreased to below limit of detection. This is potentially associated to the chemical modification of MC-LR over time as a result of its binding to intrinsic biomolecules (e.g., PPs) or its detoxification by conjugation with the GSH, catalyzed via GST (Pflugmacher et al., 2001); or simply, MC-LR was more diluted in the 2-week fruits (by increase in volume and water accumulation related to the fruit growth and maturation) leading to the inability of its detection (Gutiérrez-Praena et al., 2014). In a recent study of bioaccumulation and depuration kinetics of MC-LR in leaf tissues of lettuce, Cordeiro-Araújo et al. (2016) have shown that it is possible to decontaminate this vegetable, once lettuce gradually eliminated the accumulated MC-LR over time. However, although lettuce was capable to depurate MC-LR, when it was exposed to 5 and $10 \mu \mathrm{g} / \mathrm{L}$ for 7 days, it required approximately 29 and 37 days, respectively, to eliminate the toxin, which indicates that time is needed to recover the contaminated vegetable and higher exposure concentrations tend to turn depuration less efficient (Cordeiro-Araújo et al., 2016).

Nevertheless, Pflugmacher et al. (2001) reported that the exposure of Phragmites autralis to $0.5 \mu \mathrm{g}$ of ${ }^{14} \mathrm{C}$-labeled MC-LR/L for 3 days resulted in a rapid uptake (from $0.5 \mathrm{~h}$ ) of the toxin. The main uptake route appeared to be in the rhizome and stem, from which the toxin seemed to be transported into the higher parts of the plant. However, the authors hypothesized that uptake directly through the leaves may also occur (Pflugmacher et al., 2001). In a study performed by Crush et al. (2008), water containing toxic cyanobacteria was applied to the shoots of four different crops, and one of them (Lactuca sativa) was able to retain the toxin $(0.68 \mathrm{mg} \mathrm{MC}-\mathrm{LR} / \mathrm{kg} \mathrm{dw})$, possibly by transdermal absorption. Furthermore, MC-producing $M$. aeruginosa cells can accumulate in the leaves of spray-irrigated lettuce, and these cyanobacterial cells and MCs are not completely removed after washing (Codd et al., 1999). Another unexplored but interesting issue is related to groundwater, which can also contribute to the potential accumulation of MCs by agricultural plants. In a study conducted in situ by Mohamed and Al Shehri (2009), the MC accumulation in the leaves and roots of six vegetable plants (Raphanus sativus, Eruca sativa, Lactuca sativa, Anethum graveolens, Petroselinum hortense and Brassica oleracea) were recorded. These plants were collected from farms that used MC-contaminated groundwater $(0.3-1.8 \mu \mathrm{g} / \mathrm{L})$ for irrigation. The levels of MC in plant tissues ranged from 0.07 to $1.2 \mu \mathrm{g} / \mathrm{g}$ fresh weight, and the roots were found to accumulate significantly higher concentrations of $\mathrm{MC}$ than the leaves; these findings were positively correlated with the concentration of MCs in the groundwater wells.

The uptake mechanism of CYN by terrestrial plants has been minimally studied. In a study performed by White et al. (2005), the authors hypothesized that in the aquatic macrophyte Hydrilla verticillata, CYN is not taken up by cells, but instead is adsorbed in the plant cell walls. However, Prieto et al. (2011) detected CYN in the leaves of $O$. sativa plants, which suggests that in addition to $\mathrm{MC}$, the toxin seems to be transported through the vascular system (with an uptake at the root level via plasma membrane and symplastic transport). Because CYN is more often found in the environment in dissolved form than within cyanobacterial cells, the transdermal absorption of this toxin may be a relevant route of plant uptake (Chiswell et al., 1999; Rücker et al., 2007). Concerning the accumulation of CYN in agricultural plants, it seems to follow a similar pattern of MC-LR (Table 3). The concentration-dependent accumulation of CYN was reported in the roots and leaves of Brassica vegetables after a treatment using a cyanobacterial extract containing the toxin (Kittler et al., 2012). Prieto et al. (2011) have found the accumulation of CYN in the roots and leaves of $O$. sativa plants exposed to an extract containing $2.5 \mu \mathrm{g} \mathrm{CYN} / \mathrm{L}$, with a significantly higher concentration measured in the roots than in the leaves. Additionally, in a study developed by Silva and Vasconcelos (2010), the roots of $L$. sativa, $P$. vulgaris and $P$. sativum had higher concentrations of CYN in comparison to the stems.

From the human health perspective, it is important to emphasize that most of these studies were carried out using vegetables in which the leaves are the edible parts, and in many cases the concentration of MCs detected would exceed the tolerable daily intake (TDI) of $0.04 \mu \mathrm{g} /$ $\mathrm{kg}$ of body weight/day recommended by the World Health Organization (WHO), assuming that a person weighing $60 \mathrm{~kg}$ consumes $150 \mathrm{~g}$ or $40 \mathrm{~g}$ (Bittencourt-Oliveira et al., 2016; Cordeiro-Araújo et al., 2016) of each vegetable (Table 3). To the best of our knowledge, the only edible root vegetables that were studied with regard to MC accumulation were $R$. sativus and Eleocharis dulcis, and MC was detected in both (Mohamed and Al Shehri, 2009; Xiao et al., 2009). Because in most of the existing studies (Chen et al., 2004; Peuthert et al., 2007; Crush et al., 2008; Saqrane et al., 2009) the roots were found to accumulate higher toxin concentrations than the leaves, edible root vegetables will require increased attention with respect to food safety. Likewise, the MC-LR- or CYN- conjugates formed due to plant metabolism must be considered. The in vitro study performed by Pflugmacher et al. (2001) with the macrophyte Phragmites australis suggested that cysteine-MC and glutathione-MC conjugates may be produced during MC detoxification in plants. Although these metabolites are less toxic than MC-LR, their toxicological properties have already been described in animals (Ito et al., 2002), and they should therefore also be considered within the evaluation of the total toxicity of the MCs. To date, these potential CYN derivatives have neither been investigated nor are any analytical data available. Furthermore, the majority of the studies published are based on assessments carried out with individual cyanotoxins. However, in an aquatic or terrestrial environment, plants are exposed to several chemical contaminants simultaneously, and the interactions of each component of the mixture may result in different effects than each component applied alone, including changes in the bioaccumulation rate. A study conducted by Wang et al. (2011) showed that the uptake of MC-LR by lettuce plants was significantly higher in the presence of the anionic surfactant linear alkylbenzene sulfonate than when plants were exposed to the same concentration of MC-LR only. This finding highlights the potential for the enhancement of MC-LR and CYN accumulation in plants due to their co-occurrence with other chemical contaminants, and it underlines the importance of further research regarding the joint effects of cyanotoxin mixtures.

Finally, it is important to notice that most of these studies have been performed in hydroponic conditions, which to an extent maximizes the availability of the toxin to the root system. Therefore, the accumulation rate can be overestimated because the soil and other plant substrates can retain the toxins, reducing their bioavailability for the plants' uptake. In the only published study where a more realistic exposure scenario was created, i.e., the plants were grown in soil/ vermiculite conditions, MC accumulation did not occur (Järvenpää et al., 2007). More recently, a study performed by Kanzo et al. (2013) demonstrated that in hydroponic conditions, MCs were able to accumulate in the roots, stems and leaves of Brassica rapa after exposure to 100 and $1000 \mu \mathrm{g}$ MC-LR/L. Interestingly, in soil cultivated B. rapa, no accumulation was detected after exposure to the same MCLR concentrations. Likewise, all of the CYN studies were carried out in a soil-free cultivation system, and therefore adsorptive effects of environmental soil particles were not considered. Future studies must be designed using more realistic experimental conditions to contribute to the development of management policies regarding the use of cyanotoxin-contaminated water for irrigation and on the acceptability of these possibly contaminated plants for human consumption.

\section{MC-LR and CYN bioavailability in soil and potential implications to the groundwater quality}

In addition to the potential toxic effects for crops, the use of water 
from eutrophic systems for irrigation raises questions about the persistence of cyanotoxins in the soil, their bioavailability to plants and the groundwater contamination due to infiltration into the soil. Despite the scarcity of information available regarding the MC adsorption in cropland soils, it is suggested that the adsorption is generally low, which can potentially result in higher bioavailability for plants. However, it is known that soils with high clay and/or organic carbon contents have high adsorption coefficients of toxins. Chen et al. (2006) highlighted MC-LR as a pollutant of high mobility in soil, and mobility was mainly related to the clay content in the soil. Miller and Fallowfield (2001) found that the soils with the highest organic carbon content and the highest clay content were the most effective at removing these toxins in batch experiments. Additionally, a study developed by Järvenpää et al. (2007) demonstrated that MC elimination from the water phase by soil and vermiculite alters the concentration of the toxin available to the plants, and the success of the toxin elimination is dependent on the soil characteristics. Sandy soil (98.5\% sand) was incapable of removing cyanotoxins. This finding was supported by Morris et al. (2000), who reported that the clay content and its quality may be more important for adsorption than other soil characteristics. Chen et al. (2006) also proposed that the adsorption mechanism of MCs in soil is not only due to sorption, but also chemical binding with the metal ions on the surface of the soil particles. Due to the nitrogen and oxygen atoms in the toxin structures, MCs can chelate with the metal ions in soil clay. Moreover, the persistence of MC-LR in agricultural soils is dependent on the degradation efficiency (e.g., photolysis, hydrolysis or microbial degradation). It seems that the major dissipation process for cyanotoxins in soil ecosystems is mainly via microbial degradation (Miller and Fallowfield, 2001; Chen et al., 2006). Indeed, several soil bacteria, such as Arthrobacter sp., Brevibacterium sp. and Rhodococcus sp., appear to be able to break down MC (Manage et al., 2009). Bourne et al. (2001) also reported that Sphingomonas sp. possesses a gene cluster that is involved in MC-LR degradation. However, a recent study based on the use of radiolabeled MC-LR showed that when this cyanotoxin was introduced to a silty sand soil, it underwent a weak microbial mineralization under aerobic conditions, and therefore large amounts of the toxin remained in soil aqueous extracts (Corbel et al., 2014b). Similarly, during plant irrigation practices, a portion of the MCs may be degraded rapidly by sunlight or by some of these soil bacteria, but another portion can persist and become available in the ecosystem. Chen et al. (2006) reported that the half-life of MC-LR is between six and eighteen days. However, Corbel et al. (2015c) detected MC in soil in concentrations ranging from 1.3 and $3.9 \mathrm{ng} \mathrm{MC}-\mathrm{LR} / \mathrm{g}$ (dry soils) after 90 days of irrigation, which corroborates with the half-life of ${ }^{14} \mathrm{C}-\mathrm{MC}-\mathrm{LR}$ described by Corbel et al. (2014b), which exceeded 60 days in the same agricultural soil. No studies have yet examined the persistence of CYN in agricultural soil.

The persistence of cyanotoxins is of particular interest because it may lead to significant accumulations in soils after consecutive cycles of watering and planting. Therefore, in addition to the exposure from irrigation water containing cyanotoxins, plants may also be exposed to the toxins already present in the soil at the time of planting. Nevertheless, while soil may be able to reduce the availability of cyanotoxins to the crops, these can migrate from the surface to deeper layers of the soil following precipitation, leading to possible groundwater contamination (Chen et al., 2006). Indeed, Eynard et al. (2000) reported that the soil was not able to protect groundwater from the toxins originating from blooms occurring in the rivers and lakes of Riga, which led to the contamination of this resource. Recently, Corbel et al. (2014b) also suggested a high risk of cyanotoxins leaching from the soil toward groundwater. However, the investigation of groundwater contamination due to the use of cyanotoxin-contaminated water for crop irrigation is still in a very early stage. Further studies should be developed to investigate the real risks, especially depending on the soil characteristics and seasons. The hydrophilic characteristics of MC-LR and CYN make them very prone to leach into groundwater, and we therefore hypothesize that the use of contaminated water for irrigation or the use of harvested cyanobacterial blooms for plant fertilization are likely to cause unsafe groundwater contamination, especially in rainy seasons.

\section{Balance of risks for agriculture and public health}

Water is essential for growing agricultural plants, and its availability is becoming scarcer and of lower quality (FAO, 2012). The control of toxic cyanobacterial blooms in surface water would be the best management measure to avoid risks for agriculture and human health. However, the proliferation of these blooms has been forecasted to increase, and the use of surface water contaminated with MC-LR in agriculture has already been reported in several countries, such as Finland (Spoof et al., 2003), Spain (Aboal and Puig, 2005), Tunisia (El Herry et al., 2008), Turkey (Gurbuz et al., 2009), Morocco (Oudra et al., 2001), Saudi Arabia (Mohamed and Al Shehri, 2009), India (Prakash et al., 2009), China (Liu et al., 2011; Chen et al., 2012a), New Zealand (Wood et al., 2006), Guatemala (Romero-Oliva et al., 2014) and Algeria (Nasri et al., 2008). MC content of irrigation water examined in these studies ranged between 4 and $50 \mu \mathrm{g} / \mathrm{L}$ up to $760 \mu \mathrm{g} / \mathrm{L}$. In Algeria, however, concentrations up to 29,000 $\mu \mathrm{g} \mathrm{MC}-$ LR/L were reported (Nasri et al., 2008). CYN, which was also detected in water intended for agricultural irrigation in Australia (McGregor and Fabbro, 2000; Everson et al., 2011; Saker and Griffiths, 2001), is usually found in concentrations ranging from 2.0 to $18.9 \mu \mathrm{g} / \mathrm{L}$.

As discussed previously, the absorption of these cyanotoxins by plants is thought to induce morphological and physiological alterations, and consequently cause a putative loss of productivity due to the inhibition of germination, growth and development. However, it has recently been suggested that MC-LR and CYN are not always associated with toxic effects, and when tested in environmentally relevant concentrations $(<100 \mu \mathrm{g} / \mathrm{L})$, they may not be as harmful as initially thought, and may even accelerate plant development (Corbel et al., 2015a; Freitas et al., 2015a). Indeed, in a plant-soil system, Corbel et al. (2015b) noticed that environmental concentrations of MC-LR (0$100 \mu \mathrm{g} / \mathrm{L}$ ) had no deleterious effects on the dry weight of tomatoes (var. MicroTom), leading therefore to a significant increase in the dry weight of the aerial parts of the plant. The biological processes underlying the tolerance of plants to relevant concentrations of MCLR and CYN could be related to the increased actions of antioxidant components of the defense system (enzymatic and/or non-enzymatic) in response to oxidative stress. Therefore, the physiological stress promoted by cyanotoxins may alter the chemical composition of plants and consequently may change their nutritional quality. It has been reported that the content of minerals and non-enzymatic antioxidants, such as phenolic compounds and $\alpha$ - and $\beta$-tocopherol, were enhanced in plants after their exposure to CYN and MCs, respectively (Freitas et al., 2015a; El Khalloufi et al., 2012; Lahrouni et al., 2013; Stüven and Pflugmacher, 2007; Saqrane et al., 2009). The ability of crop plants to cope with the stress promoted by environmentally relevant concentrations of cyanotoxins also maximizes their productivity and nutritional quality, a finding that is of major relevance for agriculture and human nutrition. However, there is a significant lack of studies correlating the effects of low concentrations of cyanotoxins with the productivity and nutritional quality of agricultural plants. Nevertheless, in spite of the apparent benefits, there are attendant risks and unexpected consequences threatening food safety. Some proteins with defensive or protective functions against stress that are secreted by plants are recognized to also have allergenic potential (Abreu et al., 2013). Freitas et al. (2015b) reported an increase in the abundance of pathogenesis-related proteins that have allergenic proprieties in leaflettuce plants exposed to CYN and an MC-LR/CYN mixture. Furthermore, the potential tolerance of agricultural plants to low concentrations of MC-LR and CYN raises the possibility of its 


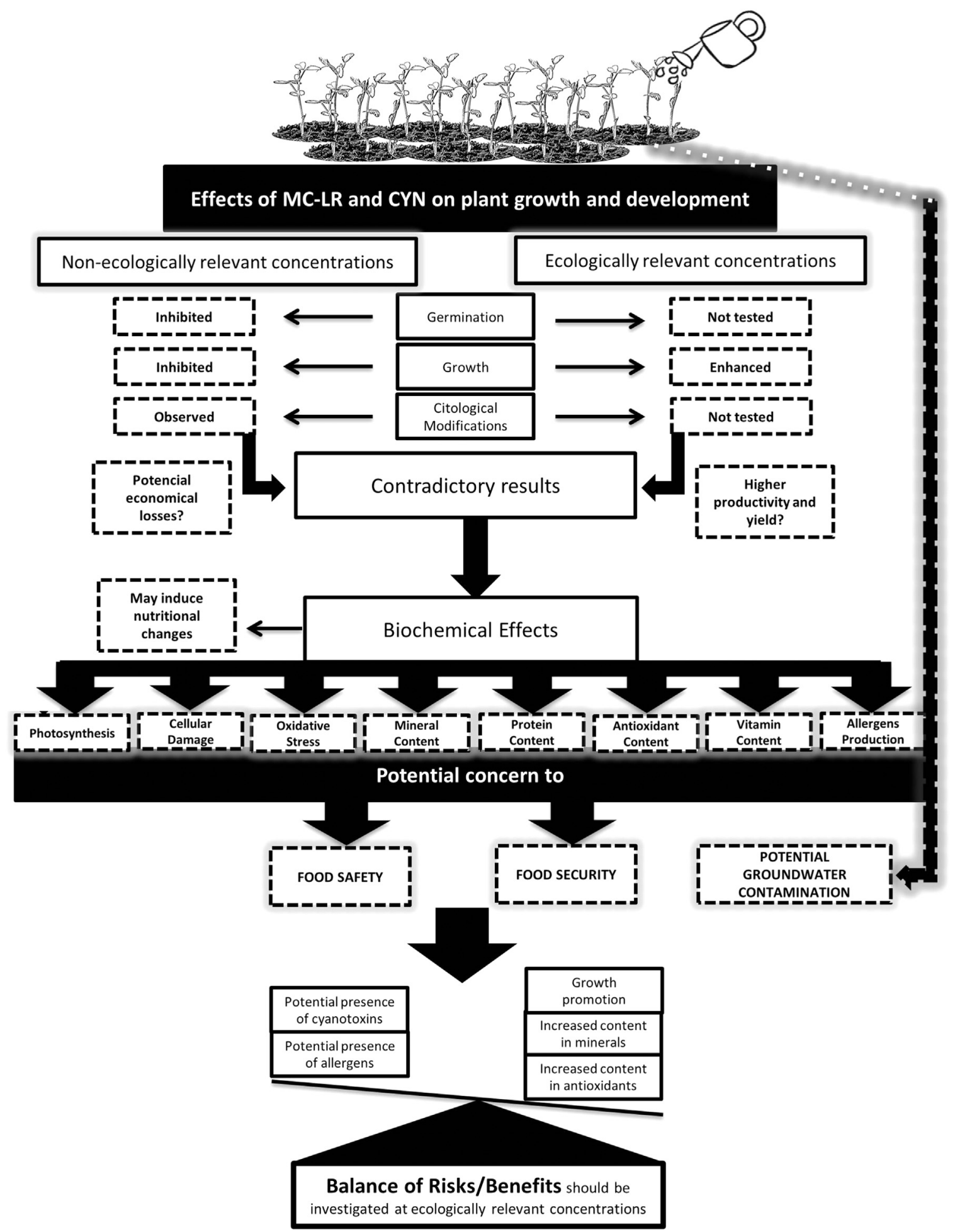

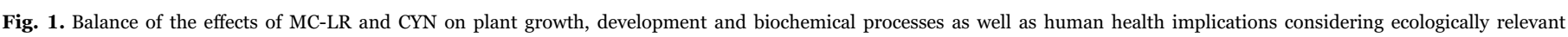
concentrations.

accumulation in edible tissues. Provisional TDI amounts of 0.04 and $0.03 \mu \mathrm{g} / \mathrm{kg}$ (body weight) were established for the presence of MC-LR and CYN in food, respectively (Sivonen and Jones, 1999; Humpage and Falconer, 2003). Although levels of CYN exceeding the TDI have not been verified, the concentration detected in the tissues of several vegetables exceeds the TDI proposed by WHO for MC-LR (assuming a consumption of $150 \mathrm{~g}$ of vegetables) (Table 3). Again, however, the accumulation studies were performed using non-ecologically relevant concentrations and with plants in the early stages of development. In light of the available information, the real impacts of cyanotoxins on agricultural plant food safety (dangerous levels of cyanotoxins and allergenic potential) are not fully understood, and more research is needed to assess the effects of realistic concentrations of cyanotoxins during a long-term exposure. In addition, another factor of uncertainty in assessing human exposure derives from the fact that it is not clear whether the levels of MC-LR and CYN measured in raw edible matrices correspond to the bioavailable amount. Freitas et al. $(2014,2016)$ have shown that factors such as food storage, processing and human 
digestion can change the MC-LR and CYN bioaccessibility and therefore the risk of human exposure. Thus, a lack of recognition of the likelihood of these hazards is an important factor for the late development of risk management strategies. The risk analysis can also be extended to an evaluation of the benefits and risks of potentially contaminated vegetable consumption in an attempt to balance the use/ restriction of MC-LR- and CYN-contaminated water for irrigation (Fig. 1). It is well recognized in the epidemiological literature that the regular consumption of vegetables has been correlated with lower risks of human chronic diseases (Boeing et al., 2012), and they are a convenient source of nutrients of fundamental importance, such as water, soluble fibers, vitamins (C, K, B2, and folic acid), minerals and phytochemicals (carotenoids). The public health impact of restrictions on the amount or type of vegetables consumed will depend on the other foods that then would substitute them, and this substitution should be appropriately weighed with the severity associated with exposure to cyanotoxins (e.g., liver cancer). Nevertheless, if it is proven that the use of water containing low concentrations of cyanotoxins does not represent a risk to consumers, a possible proactive measure to address this challenge is the addition of non-contaminated water to dilute the cyanotoxin concentrations to values that are considered risk-free. This method may be especially relevant in countries with intense water scarcity or that have no alternative to the use of cyanotoxin-contaminated water.

\section{Conclusion}

The increasing occurrence of toxic cyanobacterial blooms creates important challenges for agricultural productivity and public health.

The current literature shows that both cyanobacterial toxins, MCLR and CYN, can cause toxic effects in agricultural plants, especially at the biochemical level. Furthermore, MC-LR can accumulate in a wide range of agricultural plants, and the predicted human exposure would be higher than the TDI proposed by WHO. However, because most of these studies have been performed using cyanotoxin concentrations that are higher than those usually found in the environment and in hydroponic conditions, these effects can be overestimated in some studies because the accumulation of MC-LR and CYN seems to be dependent on the exposure concentration, and their uptake by plants can be reduced due to the adsorptive effects of soil particles and the potential biodegradation, photolysis and hydrolysis. In addition, at environmentally relevant conditions, the growth and nutritional value (antioxidant and mineral content) of some plants are enhanced as a mechanism to cope with oxidative stress. However, the potential tolerance of plants can increase their susceptibility for accumulating these cyanotoxins and allergenic proteins following long-term exposure. Therefore, further studies should be developed in this field. Furthermore, there is not sufficient information on the persistence and lifetime of these cyanotoxins in agricultural soils. This lack of information is more remarkable for CYN, and this subject should be explored in the future because of the leaching potential to groundwater. Notably, there is a need to survey the groundwater regarding the presence of these cyanotoxins, especially in the areas where contaminated water is used for irrigation. Although no appreciable risks were found at ecologically relevant concentrations, it cannot be assumed with the current data that the use of contaminated water for agricultural irrigation is free of risks to either plant productivity or public health. Irrigation water monitoring programs should be initiated, and when the concentrations of MC-LR and CYN are higher than $100 \mu \mathrm{g} / \mathrm{L}$, dilutions should be made to avoid major risks. A risk-benefit analysis would also be a valuable tool to understand the real impacts of MC-LR and CYN on agriculture and public health. Additionally, future research should also investigate the potential effects of interactions between cyanotoxins and other chemicals when present together.

\section{References}

Aboal, M., Puig, M.A., 2005. Intracellular and dissolved microcystin in reservoirs of the river Segura basin, Murcia, SE Spain. Toxicon 45 (4), 509-518. http://dx.doi.org/ 10.1016/j.toxicon.2004.12.012.

Abreu, I., Farinha, A.P., Negrão, S., Gonçalves, N., Fonseca, C., Rodrigues, M., Batista, R., Saibo, N.J.M., Oliveira, M.M., 2013. Coping with abiotic stress: proteome changes for crop improvement. J. Proteom. 93, 145-168. http://dx.doi.org/10.1016/ j.jprot.2013.07.014.

Apel, K., Hirt, H., 2004. Reactive oxygen species: metabolism, oxidative stress, and signal transduction. Annu Rev. Plant Biol. 55. http://dx.doi.org/10.1146/ annurev.arplant.55.031903.141701.

Apeldoorn, M.E., Egmond, H.P., Speijers, G.J.A., Bakker, G.J.I., 2007. Toxins of cyanobacteria. Mol. Nutr. Food Res. 51 (1), 7-60. http://dx.doi.org/10.1002/ mnfr.200600185.

Azevedo, C.C., Azevedo, J., Osório, H., Vasconcelos, V., Campos, A., 2014. Early physiological and biochemical responses of rice seedlings to low concentration of microcystin-LR. Ecotoxicology 23 (2), 107-121. http://dx.doi.org/10.1007/s10646013-1156-8.

Banker, R., Carmely, S., Hadas, O., Teltsch, B., Porat, R., Sukenik, A., 1997. Identification of cylindrospermopsin in Aphanizomenon ovalisporum (Cyanophycea) isolated from lake Kinneret, Israel. J. Phycol. 33 (4), 613-616. http://dx.doi.org/10.1111/j.00223646.1997.00613.x.

Banker, R., Teltsch, B., Sukenik, A., Carmeli, S., 2000. 7-Epicylindrospermopsin, a toxic minor metabolite of the cyanobacterium Aphanizomenon ovalisporum from lake Kinneret. J. Nat. Prod. 63 (3), 387-389. http://dx.doi.org/10.1021/np990498m.

Banker, R., Carmeli, S., Werman, M., Teltsch, B., Porat, R., Sukenik, A., 2001. Uracil moiety is required for toxicity of the cyanobacterial hepatotoxin cylindrospermopsin. J. Toxicol. Environ. Health A 62 (4), 281-288. http://dx.doi.org/10.1080/ 009841001459432.

Beyer, D., Surányi, G., Vasas, G., Roszik, J., Erdődi, F., M-Hamvas, H., Bácsi, I., Bátori, R., Serfőző, Z., Szigeti, Z.M., Vereb, G., Demeter, Z., Gonda, S., Máthé, C., 2009. Cylindrospermopsin induces alterations of root histology and microtubule organization in common reed (Phragmites australis) plantlets cultured in vitro. Toxicon 54 (4), 440-449. http://dx.doi.org/10.1016/j.toxicon.2009.05.008.

Bibo, L., Yan, G., Bangding, X., Jiantong, L., Yongding, L., 2008. A laboratory study on risk assessment of microcystin-RR in cropland. J. Environ. Manag. 86 (3), 566-574. http://dx.doi.org/10.1016/j.jenvman.2006.12.040.

Bittencourt-Oliveira, M.C., Cordeiro-Araújo, M.K., Chia, M.A., Arruda-Neto, J.D.T., de Oliveira, E.T., dos Santos, F., 2016. Lettuce irrigated with contaminated water: photosynthetic effects, antioxidative response and bioaccumulation of microcystin congeners. Ecotoxicol. Environ. Saf. 128, 83-90, http://dx.doi.org/10.1016/j.ecoenv.2016.02.014.

Boeing, H., Bechthold, A., Bub, A., Ellinger, S., Haller, D., Kroke, A., Leschik-Bonnet, E., Müller, M.J., Oberritter, H., Schulze, M., Stehle, P., Watzl, B., 2012. Critical review: vegetables and fruit in the prevention of chronic diseases. Eur. J. Nutr. 51 (6), 637-663. http://dx.doi.org/10.1007/s00394-012-0380-y.

Bourne, D.G., Riddles, P., Jones, G.J., Smith, W., Blakeley, R.L., 2001. Characterization of a gene cluster involved in bacterial degradation of the cyanobacterial toxin microcystin-LR. Environ. Toxicol. 16 (6), 523-534. http://dx.doi.org/10.1002/ tox. 10013 .

Cadenas, E., 1995. Mechanisms of oxygen activation and reactive oxygen species detoxification. In: Ahmad, S. (Ed.), Oxidative Stress and Antioxidant Defences in Biology. Chapman \& Hall, 1-61. http://dx.doi.org/10.1007/978-1-4615-9689-9_1.

Chen, J., Song, L., Dai, J., Gan, N., Zhili, L., 2004. Effects of microcystins on the growth and the activity of superoxide dismutase and peroxidade of rape (Brassica napus L.) and rice (Oryza sativa L.). Toxicon 43 (4), 393-400. http://dx.doi.org/10.1016/ j.toxicon.2004.01.011.

Chen, W., Song, L., Gan, N., Li, L., 2006. Sorption, degradation and mobility of microcystins in Chinese agriculture soils: risk assessment for groundwater protection. Environ. Pollut. 144 (3), 752-758. http://dx.doi.org/10.1016/ j.envpol.2006.02.023.

Chen, J., Dai, J., Zhang, H., Wang, C., Zhou, G., Han, Z., Liu, Z., 2010. Bioaccumulation of microcystin and its oxidative stress in the apple (Malus pumila). Ecotoxicology 19 
(4), 796-803. http://dx.doi.org/10.1007/s10646-009-0456-5.

Chen, J., Han, F.X., Wang, F., Zhang, H.Q., Shi, Z.Q., 2012a. Accumulation and phytotoxicity of microcystin-LR in rice (Oryza sativa). Ecotoxicol. Environ. Saf. 76 (2), 193-199. http://dx.doi.org/10.1016/j.ecoenv.2011.09.022.

Chen, J., Zhong, Y.M., Zhang, H.Q., Shi, Z.Q., 2012b. Nitrate reductase-dependent nitric oxide production is involved in microcystin-LR induced oxidative stress in Brassica rapa. Water Air Soil Pollut. 223 (7), 4141-4152. http://dx.doi.org/10.1007/s11270012-1180-y.

Chen, J., Zhang, H.Q., Hu, L.B., Shi, Z.Q., 2013. Microcystin-LR-induced phytotoxicity in rice crown root is associated with the cross-talk between auxin and nitric oxide. Chemosphere 93 (2), 283-293. http://dx.doi.org/10.1016/ j.chemosphere.2013.04.079.

Chiswell, R.K., Shaw, G.R., Eaglesham, G., Smith, M.J., Norris, R.L., Seawright, A.A., Moore, M.R., 1999. Stability of cylindrospermopsin, the toxin from the cyanobacterium. Cylindrospermopsis raciborskii: Effect of $\mathrm{pH}$, temperature, and sunlight on decomposition. Environ. Toxicol. 14 (1), 155-161. http://dx.doi.org/ 10.1002/(SICI)1522-7278(199902)14:1 < 155::AID-TOX20 > 3.0.CO;2-Z.

Codd, G.A., Metcalf, J.S., Beattie, K.A., 1999. Retention of Microcystis aeruginosa and microcystin by salad lettuce (Lactuca sativa) after spray irrigation with water containing cyanobacteria. Toxicon 37 (8), 1181-1185. http://dx.doi.org/10.1016/ S0041-0101(98)00244-X.

Codd, G.A., 2000. Cyanobacterial toxins, the perception of water quality, and the prioritization of eutrophication control. Ecol. Eng. 16 (1), 51-60. http://dx.doi.org/ 10.1016/S0925-8574(00)00089-6.

Corbel, S., Mougin, C., Bouaïcha, N., 2014a. Cyanobacterial toxins: modes of actions, fate in aquatic and soil ecosystems, phytotoxicity and bioaccumulation in agricultural crops. Chemosphere 96, 1-15. http://dx.doi.org/10.1016/ j.chemosphere.2013.07.056.

Corbel, S., Bouaïcha, N., Mougin, C., 2014b. Dynamics of the toxic cyanobacterial microcystin-leucine-arginine peptide in agricultural soil. Environ. Chem. Lett. 12 (4), 535-541. http://dx.doi.org/10.1007/s10311-014-0482-2.

Corbel, S., Bouaïcha, N., Nélieu, S., Mougin, C., 2015a. Soil irrigation with water and toxic cyanobacterial microcystins accelerates tomato development. Environ. Chem Lett. 13 (4), 447-452. http://dx.doi.org/10.1007/s10311-015-0518-2.

Corbel, S., Mougin, C., Martin-Laurent, F., Crouzet, O., Bur, D., Nélieu, S., Bouaïcha, N., 2015b. Evaluation of phytotoxicity and ecotoxicity potentials of a cyanobacterial extract containing microcystins under realistic environmental concentrations and in a soil-plant system. Chemosphere 128, 332-340. http://dx.doi.org/10.1016/ j.chemosphere.2015.02.008.

Corbel, S., Bouaïcha, N., Martin-Laurent, F., Crouzet, O., Mougin, C., 2015c. Soil irrigation with toxic cyanobacterial microcystins increases soil nitrification potential. Environ. Chem. Lett., 5. http://dx.doi.org/10.1007/s10311-015-0520-8.

Corbel, S., Mougin, C., Nélieu, S., Delarue, G., Bouaïcha, N., 2016. Evaluation of the transfer and the accumulation of microcystins in tomato (Solanum lycopersicum cultivar MicroTom) tissues using a cyanobacterial extract containing microcystins and the radiolabeled microcystin-LR $\left({ }^{14} \mathrm{C}-\mathrm{MC}-\mathrm{LR}\right)$. Sci. Total Environ. 541, 1052-1058, doi: http://dx.doi.org/10.1016/j.scitotenv.2015.10.004.

Cordeiro-Araújo, M.K., Chia, M.A., Arruda-Neto, J.D.T., Tornisielo, V.L., Vilca, F.Z., Bittencourt-Oliveira, M.C., 2016. Microcystin-LR bioaccumulation and depuration kinetics in lettuce and arugula: human health risk assessment. Sci. Total Environ. doi: http://dx.doi.org/10.1016/j.scitotenv.2016.05.204.

Craig, M., Luu, H.A., McCready, T.L., Williams, D., Andersen, R.J., Holmes, C.F.B., 1996. Molecular mechanisms underlying the interaction of motuporin and microcystins with type-1 and type-2A protein phosphatases. Biochem. Cell Biol. 74, 569-578. http://dx.doi.org/10.1139/096-061.

Crush, J.R., Briggs, L.R., Sprosen, J.M., Nichols, S.N., 2008. Effect of irrigation with lake water containing microcystins on microcystin content and growth of ryegrass, clover, rape, and lettuce. Environ. Toxicol. 23, 246-252. http://dx.doi.org/10.1002/ tox.20331.

Dawson, R.M., 1998. The toxicology of microcystins. Toxicon 36 (7), 953-962. http:// dx.doi.org/10.1016/S0041-0101(97)00102-5.

El Herry, S., Fathalli, A., Rejeb, A.J.B., Bouaïcha, N., 2008. Seasonal occurrence and toxicity of Microcystis spp. and Oscillatoria tenuis in the Lebna Dam, Tunisia. Water Res. 42 (4-5), 1263-1273. http://dx.doi.org/10.1016/j.watres.2007.09.019.

El Khalloufi, F., Oufdou, K., Lahrouni, M., El Ghazali, I., Saqrane, S., Vasconcelos, V., Oudra, B., 2011. Allelopatic effects of cyanobacteria extracts containing microcystins on Medicago sativa-Rhizobia symbiosis. Ecotoxicol. Environ. Saf. 74 (3), 431-438. http://dx.doi.org/10.1016/j.ecoenv.2010.10.006.

El Khalloufi, F., El Ghazali, I., Saqrane, S., Oufdou, K., Vasconcelos, V., Oudra, B., 2012. Phytotoxic effects of a natural bloom extract containing microcystins on Lycopersicon esculentum. Ecotoxicol. Environ. Saf. 79, 199-205. http://dx.doi.org/ 10.1016/j.ecoenv.2012.01.002.

El Khalloufi, F., Oufdou, K., Lahrouni, M., Faghire, M., Peix, A., Ramírez-Bahema, M., Vasconcelos, V., Oudra, B., 2013. Physiological and antioxidant responses of Medicago sativa-rhizobia symbiosis to cyanobacterial toxins (Microcystins) exposure. Toxicon 76, 167-177. http://dx.doi.org/10.1016/j.toxicon.2013.10.003.

Eynard, F., Mez, K., Walther, J.-L., 2000. Risk of cyanobacterial toxins in Riga waters (Latvia). Water Res. 34 (11), 2979-2988. http://dx.doi.org/10.1016/S00431354(00)00042-7.

Everson, S., Fabbro, L., Kinnear, S., Wright, P., 2011. Extreme differences in akinete, heterocyte and cylindrospermopsin concentrations with depth in a successive bloom involving Aphanizomenon ovalisporum (Forti) and Cylindrospermopsis raciborskii (Woloszynska) Seenaya and Subba Raju. Harmful Algae 10, 265-276. http:// dx.doi.org/10.1016/j.hal.2010.10.006.

Falconer, I.R., Humpage, A.R., 2006. Cyanobacterial (blue-green algal) toxins in water supplies: cylindrospermopsins. Environ. Toxicol. 21 (4), 299-304. http:// dx.doi.org/10.1002/tox.20194.

FAO, 2012. Coping With Water Scarcity - An Action Framework for Agriculture and Food Security. FAO Publishing. Food and Agriculture Organization of the United Nations, Rome, Italy, FAO Water Reports No. 38. Available in: http://www.fao.org/docrep/ 016/i3015e/i3015e.pdf.

Fischer, W.L., Altheimer, S., Cattori, V., Meier, P.J., Dietrich, D.R., Hagenbuch, B., 2005 Organic anion transporting polypeptides expressed in liver and brain mediate uptake of microcystin. Toxicol. Appl. Pharm. 203 (3), 257-263. http://dx.doi.org/10.1016/ j.taap.2004.08.012.

Freitas, M., Azevedo, J., Carvalho, A.P., Campos, A., Vasconcelos, V., 2014. Effects of storage, processing and proteolytic digestion on microcystin-LR concentration in edible clams. Food Chem. Toxicol. 66, 217-223. http://dx.doi.org/10.1016/ j.fct.2014.01.041.

Freitas, M., Azevedo, J., Pinto, E., Neves, J., Campos, A., Vasconcelos, V., 2015a. Effects of microcystin-LR, cylindrospermopsin and a microcystin-LR/cylindrospermopsin mixture on growth, oxidative stress and mineral content in lettuce plants (Lactuca sativa L.). Ecotoxicol. Environ. Saf. 116, 59-67. http://dx.doi.org/10.1016/ j.ecoenv.2015.02.002.

Freitas, M., Campos, A., Azevedo, J., Barreiro, A., Planchon, S., Renaut, J., Vasconcelos, V., 2015b. Lettuce (Lactuca sativa L.) leaf-proteome profiles after exposure to cylindrospermopsin and a microcystin-LR/cylindrospermopsin mixture: a concentration-dependent response. Phytochemistry 110, 91-103. http://dx.doi.org/ 10.1016/j.phytochem.2014.12.004.

Freitas, M., Azevedo, J., Carvalho, A.P., Mendes, V.M., Manadas, B., Campos, A., Vasconcelos, V., 2016. Bioaccessibility and changes on cylindrospermopsin concentration inedible mussels with storage and processing time. Food Control 59, 567-574. http://dx.doi.org/10.1016/j.foodcont.2015.06.025.

Froscio, S.M., Humpage, A.R., Burcham, P.C., Falconer, I.R., 2003. Cylindrospermopsininduced protein synthesis inhibition and its dissociation from acute toxicity in mouse hepatocytes. Environ. Toxicol. 18 (4). http://dx.doi.org/10.1002/tox.10121.

Garbers, C., DeLong, A., Deruére, J., Bernasconi, P., Söll, D., 1996. A mutation in protein phosphatase 2A regulatory subunit A affects auxin transport in Arabidopsis. EMBO J. 15 (9), 2115-2124.

Garda, T., Riba, M., Vasas, G., Beyer, D., M-Hamvas, M., Hajdu, G., Tándor, I., Máthé, C., 2015. Cytotoxic effects of cylindrospermopsin in mitotic and non-mitotic Vicia faba cells. Chemosphere 120, 145-153. http://dx.doi.org/10.1016/ j.chemosphere.2014.06.035

Garda, T., Kónya, Z., Tándor, I., Beyer, D., Vasas, G., Erdődi, F., Vereb, G., Papp, G., Riba, M., M-Hamvas, M., Máthé, C., 2016. Microcystin-LR induces mitotic spindle assembly disorders in Vicia faba by protein phosphatase inhibition and not reactive oxygen species induction. J. Plant Physiol. 199, 1-11. http://dx.doi.org/10.1016/ j.jplph.2016.04.009.

Gehringer, M.M., Kewada, V., Coates, N., Downing, T.G., 2003. The use of Lepidium sativum in a plant bioassay system for the detection of microcystin-LR. Toxicon 41 (7), 871-876. http://dx.doi.org/10.1016/S0041-0101(03)00049-7.

Grusak, M.A., 2001. Plant macro - and micronutrient minerals. eLS, 1-5. http:// dx.doi.org/10.1038/npg.els.0001306.

Gurbuz, F., Metcalf, J.S., Karahan, A.G., Codd, G.A., 2009. Analysis of dissolved microcystins in surface water samples from Kovada Lake, Turkey. Sci. Total Environ. 407 (13), 4038-4046. http://dx.doi.org/10.1016/j.scitotenv.2009.02.039.

Gutiérrez-Praena, D., Campos, A., Azevedo, J., Neves, J., Freitas, M., Guzmán-Guillén, R., Cameán, A.M., Renaut, J., Vasconcelos, V., 2014. Exposure of Lycopersicon esculentum to microcystin-LR: effects in the leaf proteome and toxin translocation from water to leaves and fruits. Toxins 6 (6), 1837-1854. http://dx.doi.org/ $10.3390 /$ toxins6061837.

Harada, K.I., Ohtani, I., Iwamoto, K., Suzuki, M., Watanabe, M., Watanabe, F., Terao, K., 1994. Isolation of cylindrospermopsin from a cyanobacterium Umezakia natans and its screening method. Toxicon 32 (1), 73-84. http://dx.doi.org/10.1016/00410101(94)90023-X.

Hitzfeld, B.C., Höger, S.J., Dietrich, D.R., 2000. Cyanobacterial toxins: removal during drinking water treatment and human risk assessment. Environ. Health Perspect. 108 (S1), S113-S122. http://dx.doi.org/10.1289/ehp.00108s1113.

Humpage, A.R., Falconer, I.R., 2003. Oral toxicity of the cyanobacterial toxin cylindrospermopsin in male swiss albino mice: determination of no observed adverse effect level for deriving a drinking water guideline value. Environ. Toxicol. 18 (2), 94-103. http://dx.doi.org/10.1002/tox.10104.

Humpage, A.R., Fontaine, F., Froscio, S., Burcham, P., Falconer, I.R., 2005. Cylindrospermopsin genotoxicity and cytotoxicity: role of cytochrome P-450 and oxidative stress. J. Toxicol. Environ. Health A 68, 739-753. http://dx.doi.org/ $10.1080 / 15287390590925465$.

IARC (2010). Ingested Nitrate and Nitrite, and Cyanobacterial Peptide Toxins, IARC Monogr Eval Carcinog Risks Hum Suppl, 94, Lyon, France. pp. 327-412. ISSN 1014-711X. Available in: 〈http://monographs.iarc.fr/ENG/Monographs/suppl7/ suppl7.pdf $\rangle$

Ito, E., Takaib, A., Kondoc, F., Masuid, H., Imanishid, S., Harada, K.-i, 2002. Comparison of protein phosphatase inhibitory activity and apparent toxicity of microcystins and related compounds. Toxicon 40 (7), 1017-1025. http://dx.doi.org/10.1016/S00410101(02)00099-5.

Järvenpää, S., Lundberg-Niinistö, C., Spoof, L., Sjövall, O., Tyystjärvi, E., Meriluoto, J., 2007. Effects of microcystins on broccoli and mustard, and analysis of accumulated toxin by liquid chromatography-mass spectrometry. Toxicon 49 (6), 865-874. http://dx.doi.org/10.1016/j.toxicon.2006.12.008.

Kanzo, Y., Ruike, K., Inamori, R., Suzuki, R., Xu, K.-q, Inamori, 2013. Analysis of absorption and accumulation of blue-green algae toxin Microcystin in the Komatsuna cultivation. J. Bioind. Sci. 2 (1), 12-16.

Kinnear, S., 2010. Cylindrospermopsin: a decade of progress on bioaccumulation 
research. Mar. Drugs 8, 542-564. http://dx.doi.org/10.3390/md8030542.

Kittler, K., Schreiner, M., Krumbein, A., Manzei, S., Koch, M., Rohn, S., Maul, R., 2012. Uptake of the cyanobacterial toxin cylindrospermopsin in Brassica vegetables. Food Chem. 133 (3), 875-879. http://dx.doi.org/10.1016/j.foodchem.2012.01.107.

Kist, L.W., Rosemberg, D.B., Pereira, T.C., Azevedo, M.B., Richetti, S.K., Castro Leão, J., Yunes, J.C., Bonan, C.D., Bogo, M.R., 2012. Microcystin-LR acute exposure increases AChE activity via transcriptional ache activation in zebrafish (Danio rerio) brain. Comp. Biochem. Physiol. C: Toxicol. Pharmacol. 155 (2), 247-252. http:// dx.doi.org/10.1016/j.cbpc.2011.09.002.

Kuiper-Goodman, T., Falconer, I., Fitzgerals, J., 1999. Human health aspects. In: Chorus, I., Bartam, J. (Eds.), Toxic Cyanobacteria in Water: A Guide to Their Public Health Consequences, Monitoring and Management. WHO, Geneve, 113-160.

Kurki-Helasmo, K., Meriluoto, J., 1998. Microcystin uptake inhibits growth and protein phosphatase activity in mustard (Sinapis alba L.) seedlings. Toxicon 36 (12), 1921-1926. http://dx.doi.org/10.1016/S0041-0101(98)00114-7.

Lahrouni, M., Oufdou, K., Fanghire, M., Peix, A., El Khalloufi, F., Vasconcelos, V., Oudra, B., 2012. Cyanobacterial extracts containing microcystins affect the growth, nodulation process and nitrogen uptake of faba bean (Vicia faba L., Fabaceae). Ecotoxicology 21 (3), 681-687. http://dx.doi.org/10.1007/s10646-011-0826-7.

Lahrouni, M., Oufdou, K., El Khalloufi, F., Baz, M., Lafuente, A., Dary, M., Pajuelo, E., Oudra, B., 2013. Physiological and biochemical defense reactions of Vicia faba L.Rhizobium symbiosis face to chronic exposure to cyanobacterial bloom extract containing microcystins. Environ. Sci. Pollut. Res. Int. 20 (8), 5405-5415. http:// dx.doi.org/10.1007/s11356-013-1535-y.

Li, R., Carmichael, W.W., Brittain, S., Eaglesham, G.K., Shaw, G.R., Liu, Y., Watanabe, M.M., 2001. First report of the cyanotoxins cylindrospermopsin and deoxycylindrospermopsin from Raphidiopsis curvata (Cyanobacteria). J. Phycol. 37 (6), 1121-1126. http://dx.doi.org/10.1046/j.1529-8817.2001.01075.x.

Liu, Y., Chen, W., Li, D., Huang, Z., Shen, Y., Liu, Y., 2011. Cyanobacteria-/cyanotoxin contaminations and eutrophication status before Wuxi drinking water crisis in Lake Taihu, China. J. Environ. Sci. 23 (4), 575-581.

Luan, S., 1998. Protein phosphatases and signaling cascades in higher plants. Trends Plant Sci. 3, 271-275, doi: http://dx.doi.org/10.1016/S1360-1385(98)01258-8.

MacKintosh, C., Beattie, K.A., Klumpp, S., Cohen, P., Codd, G.A., 1990. Cyanobacterial microcystin-LR is a potent and specific inhibitor of protein phosphatases 1 and 2A from both mammals and higher plants. FEBS Lett. 264 (2), 187-192. http:// dx.doi.org/10.1016/0014-5793(90)80245-E.

MacKintosh, R.W., Dalby, K.N., Campbell, D.G., Cohen, P.T.W., Cohen, P., Mackintosh, C., 1995. The cyanobacterial toxin microcystin binds covalently to cysteine-273 on protein phosphatase 1. FEBS Lett. 371 (3), 236-240. http://dx.doi.org/10.1016/ 0014-5793(95)00888-G.

Manage, P.M., Edwards, C., Singh, B.K., Lawton, L.A., 2009. Isolation and identification of novel microcystin-degrading bacteria. Appl. Environ. Microbiol. 75 (21), 6924-6928. http://dx.doi.org/10.1128/AEM.01928-09.

Máthé, C., M-Hamvas, M., Vasas, G., 2013a. Microcystin-LR and cylindrospermopsin induced alterations in chromatin organization of plant cells. Mar. Drugs 11 (10), 3689-3717. http://dx.doi.org/10.3390/md11103689.

Máthé, C., Vasas, G., Borbély, G., Erdődi, F., Beyer, D., Kiss, A., Surányi, G., Gonda, S., Jámbri, K., M-Hamvas, M., 2013b. Histological, cytological and biochemical alterations induced by microcystin-lr and cylindrospermopsin in white mustard (Sinapis alba L.) seedlings. Acta Biol. Hung. 64 (1), 71-85, doi:http://dx.doi.org/10.1556/ABiol.64.2013.1.7.

McElhiney, J., Lawton, L.A., Leifert, C., 2001. Investigations into the inhibitory effects of microcystins on plant growth, and the toxicity of plant tissues following exposure. Toxicon 39 (9), 1411-1420. http://dx.doi.org/10.1016/S0041-0101(01)00100-3.

McGregor, G.B., Fabbro, L.D., 2000. Dominance of Cylindrospermopsis raciborskii (Nostocales, Cyanoprokaryota) in Queensland tropical and subtropical reservoirs: implications for monitoring and management. Lakes Reserv. Res. Manag. 5 (3), 195-205. http://dx.doi.org/10.1046/j.1440-1770.2000.00115.x.

Merel, S., Walker, D., Chicana, R., Snyder, S., Baurès, E., Thomas, O., 2013. State of knowledge and concerns on cyanobacterial blooms and cyanotoxins. Environ. Int. 59, 303-327. http://dx.doi.org/10.1016/j.envint.2013.06.013.

Metcalf, J.S., Barakate, A., Codd, G.A., 2004. Inhibition of plant protein synthesis by the cyanobacterial hepatotoxin, cylindrospermopsin. FEMS Microbiol. Lett. 235, 125-129. http://dx.doi.org/10.1111/j.1574-6968.2004.tb09576.x.

M-Hamvas, M., Máthé, C., Molnár, E., Vasas, G., Grigorszky, I., Borbely, G., 2003 Microcystin-LR alters the growth, anthocyanin content and single-stranded DNase enzyme activities in Sinapis alba L seedlings. Aquat. Toxicol. 62 (1), 1-9. http:// dx.doi.org/10.1016/S0166-445X(01)00273-9.

Miller, M.J., Fallowfield, H.J., 2001. Degradation of cyanobacterial hepatotoxins in batch experiments. Water Sci. Technol. 43 (12), 229-232.

Milutinovic, A., Zorc-Pleskovic, R., Petrovic, D., Zorc, M., Suput, D., 2006. MicrocystinLR induces alterations in heart muscle. Folia Biol. 52 (4), 116-118.

Mohamed, Z., Al Shehri, A.M., 2009. Microcystins in groundwater wells and their accumulation in vegetable plants irrigated with contaminated waters in Saudi Arabia. J. Hazard. Mater. 172 (1), 310-315. http://dx.doi.org/10.1016/ j.jhazmat.2009.07.010.

Morris, R.J., Williams, D.E., Luu, H.A., Holmes, C.F.B., Andersen, R.J., Calvert, S.E., 2000. The adsorption of microcystin-LR by natural clay particles. Toxicon 38, 303-308, doi: http://dx.doi.org/10.1016/S0041-0101(99)00149-X.

Mur, L.R., Skulberg, O.M., Utkilen, H., 1999. Cianobacteria in the environment. In Chorus, I., Bartram, J. (Eds.), Toxic Cyanobacteria in Water: A Guide to Their Public Health Consequences, Monitoring and Management. E c FN Spon, London, 15-40.

Nasri, H., El Herry, S., Bouaïcha, N., 2008. First reported case of turtle deaths during a toxic Microcystis spp. bloom in Lake Oubeira Algeria. Ecotoxicol. Environ. Saf. 71 (2), 535-544. http://dx.doi.org/10.1016/j.ecoenv.2007.12.009.
Noctor, G., Foyer, C.H., 1998. Ascorbate and glutathione. Keeping active oxygen under control. Annu Rev. Plant Physiol. Plant Mol. Biol. 49, 249-279. http://dx.doi.org/ 10.1146/annurev.arplant.49.1.249.

Norris, R.L.G., Eaglesham, G.K., Pierens, G., Shaw, G.R., Smith, M.J., Chiswell, R.K., Seawright, A.A., Moore, M.R., 1999. Deoxycylindrospermopsin, an analog of cylindrospermopsin from Cylindrospermopsis raciborskii. Environ. Toxicol. 14 (1), 163-165. http://dx.doi.org/10.1002/(SICI)1522-7278(199902)14:1 < 163::AIDTOX21 > 3.0.CO;2-V

Norris, R.L., Seawright, A.A., Shaw, G.R., Senogles, P., Eaglesham, G.K., Smith, M.J., Chiswell, R.K., Moore, M.R., 2002. Hepatic xenobiotic metabolism of cylindrospermopsin in vivo in the mouse. Toxicon 40 (4), 471-476. http:// dx.doi.org/10.1016/S0041-0101(01)00243-4.

OECD (2005). Emerging Risks to Water Supplies: Best Practice for Improved Management and Preparedness to Protect Public Health.

Ohtani, I., Moore, R.E., Runnegar, M.T.C., 1992. Cylindrospermopsin: a potent hepatotoxin from the blue-green alga Cylindrospermopsis raciborskii. J. Am. Chem. Soc. 114 (20), 7941-7942. http://dx.doi.org/10.1021/ja00046a067.

O’Neil, J.M., Davis, T.W., Burford, M.A., Gobler, C.J., 2012. The rise of harmful cyanobacteria blooms: the potential roles of eutrophication and climate change. Harmful Algae 14, 313-334. http://dx.doi.org/10.1016/j.hal.2011.10.027.

Oudra, B., Loudiki, M., Sbiyyaa, B., Martins, R., Vasconcelos, V., Namikoshi, N., 2001. Isolation, characterization and quantification of microcystins (heptapeptides hepatotoxins) in Microcystis aeruginosa dominated bloom of Lalla Takerkoust lakereservoir (Morocco). Toxicon 39 (9), 1375-1381. http://dx.doi.org/10.1016/S00410101(01)00093-9.

Pereira, S., Saker, M., Vale, M., Vasconcelos, V., 2009. Comparison of sensitivity of grasses (Lolium perenne L. and Festuca rubra L.) and lettuce (Lactuca sativa L.) exposed to water contaminated with microcystins. Bull. Environ. Contam. Toxicol. 83 (1), 81-84. http://dx.doi.org/10.1007/s00128-009-9763-z.

Peuthert, A., Chakrabarti, S., Pflugmacher, S., 2007. Uptake of microcystins-LR and -LF (cyanobacterial toxins) in seedlings of several important agricultural plant species and the correlation with cellular damage (lipid peroxidation). Environ. Toxicol. 22, 436-442. http://dx.doi.org/10.1897/05-615R.1.

Peuthert, A., Pflugmacher, S., 2010. Influence of the cyanotoxin microcystin-LR on tocopherol in Alfafa seedlings (Medicado sativa). Toxicon 56, 411-417, doi: http://dx.doi.org/10.1016/j.toxicon.2013.10.003.

Pflugmacher, S., 2004. Promotion of oxidative stress in the aquatic macrophyte Ceratophyllum demersum during biotransformation of the cyanobacterial toxin microcystin-LR. Aquat. Toxicol. 70 (3), 169-178. http://dx.doi.org/10.1016/ j.aquatox.2004.06.010.

Pflugmacher, S., 2007. Reduction in germination rate and elevation of peroxidase activity in Zea mays seedlings due to exposure to different microcystin analogues and toxic cell free cyanobacterial crude extract. J. Appl. Bot. Food 81 (1), 45-48.

Pflugmacher, S., Wiegand, C., Beattie, K.A., Krause, E., Steinberg, C.E.W., Codd, G.A., 2001. Uptake, effects, and metabolism of cyanobacterial toxins in the emergent reed plant Phragmites australis (cav.) trin. ex steud. Environ. Toxicol. Chem. 20 (4), 846-852. http://dx.doi.org/10.1002/etc.5620200421.

Pflugmacher, S., Jung, K., Lundvall, L., Neumann, S., Peuthert, A., 2006. Effects of cyanobacterial toxins and cyanobacterial cell-free crude extract on germination of alfalfa (Medicago sativa) and induction of oxidative stress. Environ. Toxicol. Chem. 25 (9), 2381-2387. http://dx.doi.org/10.1897/05-615R.1.

Pflugmacher, S., Aulhorn, M., Grimm, B., 2007a. Influence of a cyanobacterial crude extract containing microcystin-LR on the physiology and antioxidative defence systems of different spinach variants. New Phytol. 175 (3), 482-489. http:// dx.doi.org/10.1111/j.1469-8137.2007.02144.x.

Pflugmacher, S., Hofmann, J., Hübner, B., 2007b. Effects on growth and physiological parameters in wheat (Triticum aestivum L.) grown in soil and irrigated with cyanobacterial toxin contaminated water. Environ. Toxicol. Chem. 26 (12), 2710-2716. http://dx.doi.org/10.1897/07-145.1.

Pichardo, S., Pflugmacher, S., 2011. Study of the antioxidant response of several bean variants to irrigation with water containing MC-LR and cyanobacterial crude extract. Environ. Toxicol. 26 (3), 300-306. http://dx.doi.org/10.1002/tox.20622.

Poniedziałek, B., Rzymski, P., Kokociński, M., 2012. Cylindrospermopsin: water-linked potential threat to human health in Europe. Environ. Toxicol. Pharm. 34 (3), 651-660. http://dx.doi.org/10.1016/j.etap.2012.08.005.

Prakash, S., Lawton, L.A., Edwards, C., 2009. Stability of toxigenic Microcystis blooms. Harmful Algae 8 (3), 377-384. http://dx.doi.org/10.1016/j.hal.2008.08.014.

Preussel, K., Stuken, A., Wiedner, C., Chorus, I., Fastner, J., 2006. First report on cylindrospermopsin producing Aphanizomenon flos-aquae (Cyanobacteria) isolated from two German lakes. Toxicon 47 (2), 156-162. http://dx.doi.org/10.1016/ j.toxicon.2005.10.013.

Prieto, A., Campos, A., Cameán, A., Vasconcelos, V., 2011. Effects on growth and oxidative stress status of rice plants (Oryza sativa) exposed to two extracts of toxinproducing cyanobacteria (Aphanizomenon ovalisporum and Microcystis aeruginosa). Ecotoxicol. Environ. Saf. 74 (7), 1973-1980. http://dx.doi.org/ 10.1016/j.ecoenv.2011.06.009.

Puddick, J., Prinsep, M.R., Wood, S.A., Kaufononga, S.A., Cary, S.C., Hamilton, D.P., 2014. High levels of structural diversity observed in microcystins from microcystis CAWBG11 and characterization of six new microcystin congeners. Mar. Drugs 12 (11), 5372-5395. http://dx.doi.org/10.3390/md12115372.

Qi, Y., Rosso, L., Sedan, D., Giannuzzi, L., Andrinolo, D., Volmer, D.A., 2015. Seven new microcystin variants discovered from a native Microcystis aeruginosa strainunambiguous assignment of product ions by tandem mass spectrometry. Rapid Commun. Mass Spectrom. 29 (2), 220-224. http://dx.doi.org/10.1002/rcm.7098.

Qin, W., Xu, L., Zhang, X., Wang, Y., Meng, X., Miao, A., Yang, L., 2010. Endoplasmic reticulum stress in murine liver and kidney exposed to microcystin-LR. Toxicon 56 
(8), 1334-1341. http://dx.doi.org/10.1016/j.toxicon.2010.07.017.

Rajeshwari, K.R., Rajashekhar, M., 2011. Biochemical composition of seven species of cyanobacteria isolated from different aquatic habitats of Western Ghats, Southern India. Braz. Arch. Biol. Technol. 54 (5),

849-857, doi: http://dx.doi.org/10.1590/S1516-89132011000500001.

Romero-Oliva, C.-S., Contardo-Jara, V., Block, T., Pflugmacher, S., 2014. Accumulation of microcystin congeners in different aquatic plants and crops-a case study from lake Amatitlán, Guatemala. Ecotoxicol. Environ. Saf. 102, 121-128. http://dx.doi.org/ 10.1016/j.ecoenv.2014.01.031.

Rücker, J., Stüken, A., Nixdorf, B., Fastner, J., Chorus, I., Wiedner, C., 2007. Concentrations of particulate and dissolved cylindrospermopsin in 21 Aphanizomenon-dominated temperate lakes. Toxicon 50 (6), 800-809. http:// dx.doi.org/10.1016/j.toxicon.2007.06.019.

Runnegar, M.T., Kong, S.M., Zhong, Y.Z., Lu, S.C., 1995. Inhibition of reduced glutathione synthesis by cyanobacterial alkaloid cylindrospermopsin in cultured rat hepatocytes. Biochem. Pharm. 49 (2), 219-225. http://dx.doi.org/10.1016/S00062952(94)00466-8.

Runnegar, M.T., Xie, C., Snider, B.B., Wallace, G.A., Weinreb, S.M., Kuhlenkamp, J. 2002. In vitro hepatotoxicity of the cyanobacterial alkaloid cylindrospermopsin and related synthetic analogues. Toxicol. Sci. 67 (1), 81-87. http://dx.doi.org/10.1093/ toxsci/67.1.81.

Saker, M.L., Griffiths, D.J., 2001. Occurrence of blooms of the cyanobacterium Cylindrospermopsis raciborskii (Woloszynska) Seenayya and Subba Raju in a north Queensland domestic water supply. Mar. Freshw. Res. 52 (6), 907-915. http:// dx.doi.org/10.1071/MF00110.

Saqrane, S., Ghazali, I.E., Oudra, B., Bouarab, L., Vasconcelos, V., 2008. Effect of cyanobacteria producing microcystins on seed germination and seedling growth of several agricultural plants. J. Environ. Sci. Health B 43 (5), 443-451. http:// dx.doi.org/10.1080/10934520701796192.

Saqrane, S., Ouahid, Y., El Ghazali, I., Oudra, B., Bouarab, L., del Campo, F.F., 2009. Physiological changes in Triticum durum, Zea mays, Pisum sativum and Lens esculenta cultivars, caused by irrigation with water contaminated with microcystins: a laboratory experimental approach. Toxicon 53 (7-8), 786-796. http://dx.doi.org/ 10.1016/j.toxicon.2009.01.028.

Schembri, M.A., Neilan, B.A., Saint, C.P., 2001. Identification of genes implicated in toxin production in the cyanobacterium Cylindrospermopsis raciborskii. Environ. Toxicol. 16 (5), 413-421. http://dx.doi.org/10.1002/tox.1051.

Seifert, M., McGregor, G., Eaglesham, G., Wickramasinghe, W., Shaw, G., 2007. First evidence for the production of cylindrospermopsin and deoxy-cylindrospermopsin by the freshwater benthic cyanobacterium, Lyngbya wollei (Farlow ex Gomont) Speziale and Dyck. Harmful Algae 6 (1), 73-80. http://dx.doi.org/10.1016/ j.hal.2006.07.001.

Sheen, J., 1993. Protein phosphatase activity is required for light-inducible gene expression in maize. EMBO J. 12, 3497-350.

Siegl, G., MacKintosh, C., Stitt, M., 1990. Sucrose-phosphate synthase is dephosphorylated by protein phosphatase 2A in spinach leaves: evidence from the effects of okadaic acid and microcystin. FEBS Lett. 270, 198-202. http://dx.doi.org/ 10.1016/0014-5793(90)81267-R.

Silva, P., Vasconcelos, V., 2010. Allelopathic effect of Cylindrospermopsis raciborskii extracts on the germination and growth of several plant species. J. Chem. Ecol. 26 (4), 263-271. http://dx.doi.org/10.1080/02757540.2010.495060.

Sivonen, K., Jones, G., 1999. Cyanobacterial toxins. In: Chorus, I., Bartram, J. (Eds.), Toxic Cyanobacteria in Water: A Guide to Their Public Health Consequences, Monitoring And Management. World Health Organization, Taylor and Francis, London and New York, 41-111.

Smith, R.D., Walker, J.C., 1996. Plant protein phosphatases. Annu Rev. Plant Physiol. Plant Mol. Biol. 47, 101-125. http://dx.doi.org/10.1146/annurev.arplant.47.1.101.

Smith, V.H., Tilman, G.D., Nekola, J.C., 1999. Eutrophication: impacts of excess nutrient inputs on freshwater, marine, and terrestrial ecosystems. Environ. Pollut. 100 (1-3), 179-196. http://dx.doi.org/10.1016/S0269-7491(99)00091-3.

Spoof, L., Vesterkvist, P., Lindholm, T., Meriluoto, J., 2003. Screening for cyanobacterial hepatotoxins, microcystins and nodularin in environmental water samples by reversed-phase liquid chromatography-electrospray ionisation mass spectrometry. J. Chromatogr. A 1020 (1), 105-119. http://dx.doi.org/10.1016/S0021-9673(03) 00428-X.

Spoof, L., Berg, K.A., Rapala, J., Lahti, K., Lepisto, L., Metcalf, J.S., Codd, G.A., Meriluoto, J., 2006. First observation of cylindrospermopsin in Anabaena lapponica isolated from the boreal environment (Finland). Environ. Toxicol. 21 (6), 552-560. http://dx.doi.org/10.1002/tox.20216.

Stüven, J., Pflugmacher, S., 2007. Antioxidative stress response of Lepidium sativum due to exposure to cyanobacterial secondary metabolites. Toxicon 50 , 85-93, doi: http://dx.doi.org/10.1016/j.toxicon.2007.02.019.
Sukenik, A., Banker, R., Carmeli, S., Werman, M., Teltsch, B., Porat, R. (2001). Proposed toxicity mode of cylindrospermopsin (cyanobacterial hepatotoxin based on its structurally related derivatives. In: Proceedings of the Fifth International Conference on Toxic Cyanobacteria Towards a Global Perspective on Toxic Cyanobacteria, Noosa, Queensland, Australia, pp. 16-20.

Taiz, L., Zeiger, E., 2002. Plant Physiology third edition. Sinauer Associates, Sunderland, MA, 690 pp.

Takeda, S., Mano, S., Ohto, M., Nakamura, K., 1994. Inhibitors of protein phosphatases 1 and $2 \mathrm{~A}$ block the sugar-inducible gene expression in plants. Plant Physiol. 106 567-574, doi: http://dx.doi.org/10.1104/pp.106.2.567.

Tegeder, M., Rentsch, D., 2010. Uptake and partitioning of amino acids and peptides. Mol. Plant 3, 997-1011. http://dx.doi.org/10.1093/mp/ssq047.

Terao, K., Ohmori, S., Igarashi, K., Ohtani, I., Watanabe, M.F., Harada, K.I., Ito, E., Watanabe, M., 1994. Electron microscopic studies on experimental poisoning in mice induced by cylindrospermopsin isolated from blue-green alga Umezakia natans. Toxicon 32 (7), 833-843. http://dx.doi.org/10.1016/0041-0101(94)90008-

Toroser, D., Huber, S.C., 2000. Carbon and nitrogen metabolism and reversible protein phosphorylation. Adv. Bot. Res. 32, 435-458, http://dx.doi.org/10.1016/S0065-2296(00)32032-8.

Ueno, Y., Nagata, S., Tsutsumi, T., Hasegawa, A., Watanabe, M.F., Park, H.D., Chen, G.C., Chen, G., Yu, S.Z., 1996. Detection of microcystins, a blue-green algal hepatotoxins, in drinking water sampled in Haimen and Fusui, endemic areas of primary liver cancer in China, by highly sensitive immunoassay. Carcinogenesis 17 (6), 1317-1321. http://dx.doi.org/10.1093/carcin/17.6.1317.

Vasas, G., Gáspár, A., Surányi, G., Batta, G., Gyémánt, G., M-Hamvas, M., Máthé, C., Grigorszky, I., Molnár, E., Borbély, G., 2002. Capillary electrophoretic assay and purification of cylindrospermopsin, a cyanobacterial toxin from Aphanizomenon ovalisporum, by plant test (blue-green Sinapis test). Anal. Biochem. 302, 95-103. http://dx.doi.org/10.1006/abio.2001.5525.

Vasconcelos, V., 2006. Eutrophication, toxic cyanobacteria and cyanotoxins: when ecosystems cry for help. Limnetica 25 (1-2), 425-432.

Wang, Z., Xiao, B., Song, L., Wu, X., Zhang, J., Wang, C., 2011. Effects of microcystin-LR, linear alkylbenzene sulfonate and their mixture on lettuce (Lactuca sativa L.) seeds and seedlings. Ecotoxicology 20 (4), 803-814. http://dx.doi.org/10.1007/s10646011-0632-2.

White, S.H., Duivenvoorden, L.J., Fabbro, L.D., 2005. Absence of freecylindrospermopsin bioconcentration in water thyme (Hydrilla verticillata). Bull. Environ. Contam. Toxicol. 75, 574-583. http://dx.doi.org/10.1007/s00128-0050790-0.

WHO, 2011. Cyanobacterial toxins: microcystin-LR. Guidelines for Drinking-water Quality, 4th ed. World Health Organization, Geneva, Switzerland. 〈http://www.who. int/water_sanitation_health/publications/2011/dwq_guidelines/en/ $\rangle$.

Wood, S.A., Briggs, L.R., Sprosen, J., Ruck, J.G., Wear, R.G., Holland, P.T., Bloxham, M., 2006. Changes in concentrations of microcystins in rainbow trout, freshwater mussels, and cyanobacteria in Lakes Rotoiti and Rotoehu. Environ. Toxicol. 21, 205-222. http://dx.doi.org/10.1002/tox.20174.

Wörmer, L., Huerta-Fontela, M., Cirés, S., Carrasco, D., Quesada, A., 2010. Natural photodegradation of the cyanobacterial toxins microcystin and cylindrospermopsin. Environ. Sci. Technol. 44 (8), 3002-3007. http://dx.doi.org/10.1021/es9036012.

Wu, J., Shao, S., Zhou, F., Wen, S., Chen, F., Han, X., 2014. Reproductive toxicity on female mice induced by microcystin-LR. Environ. Toxicol. Pharmacol. 37 (1), 1-6. http://dx.doi.org/10.1016/j.etap.2013.10.012.

Xiao, F.-G., Zhao, X.-L., Tang, J., Gu, X.-H., Zhang, J.-P., Ni, W.-M., 2009. Necessity of screening water Chestnuts for microcystins after cyanobacterial blooms break out. Arch. Environ. Contam. Toxicol. 57 (2), 256-263. http://dx.doi.org/10.1007/ s00244-008-9275-6.

Yu, S.Z., 1995. Primary prevention of hepatocellular carcinoma. J. Gastroenterol. Hepatol. 10 (6), 674-682. http://dx.doi.org/10.1111/j.1440-1746.1995.tb01370.x.

Zhou, L., Yu, H., Chen, K., 2002. Relationship between microcystin in drinking water and colorectal cancer. Biomed. Environ. Sci. 15 (2), 166-171.

Zhou, M., Wei-wei, Tu, Xu, J., 2015. Mechanisms of microcystin-LR-induced cytoskeletal disruption in animal cells. Toxicon 101, 92-100. http://dx.doi.org/10.1016/ j.toxicon.2015.05.005.

Zegura, B., Zajc, I., Lah, T.T., Filipič, M., 2008. Patterns of microcystin-LR induced alteration of the expression of genes involved in response to DNA damage and apoptosis. Toxicon 51 (4), 615-623. http://dx.doi.org/10.1016/ j.toxicon.2007.11.009.

Zegura, B., Straser, A., Filipič, M., 2011. Genotoxicity and potential carcinogenicity of cyanobacterial toxins - a review. Mutat. Res. 727, 16-41. http://dx.doi.org/ 10.1016/j.mrrev.2011.01.002. 